\title{
Genomic signatures of parasite-driven natural selection in north European Atlantic salmon (Salmo salar)
}

\section{Zueva, Ksenia J.}

2018-06

Zueva, K J , Lumme , J , Veselov , A E , Kent , M P \& Primmer , C R 2018 , ' Genomic signatures of parasite-driven natural selection in north European Atlantic salmon (Salmo salar) ' , Marine Genomics , vol. 39 , pp. 26-38 . https://doi.org/10.1016/j.margen.2018.01.001

http://hdl.handle.net/10138/315575

https://doi.org/10.1016/j.margen.2018.01.001

cc_by_nc_nd

acceptedVersion

Downloaded from Helda, University of Helsinki institutional repository.

This is an electronic reprint of the original article.

This reprint may differ from the original in pagination and typographic detail.

Please cite the original version. 
1 Genomic signatures of parasite-driven natural selection in north European

Ksenia J. Zueva ${ }^{1}$, Jaakko Lumme $^{2}$, Alexey E. Veselov ${ }^{3}$, Matthew P. Kent ${ }^{4}$, Craig R.

\section{Atlantic salmon (Salmo salar).}

${ }^{1}$ Department of Biology, University of Turku, Turku, Finland ksezue@utu.fi

${ }^{2}$ Department of Biology, University of Oulu, Oulu, Finland

${ }^{3}$ Institute of Biology of the Karelian Research Centre, Petrozavodsk, Russia

${ }^{4}$ Centre for Integrative Genetics, Department of Animal and Aquacultural Sciences, Faculty of Biosciences, Norwegian University of Life Sciences, Ås, Norway

${ }^{5}$ Department of Biosciences, University of Helsinki, Helsinki, Finland

${ }^{6}$ Institute of Biotechnology, University of Helsinki, Helsinki, Finland 


\section{ABSTRACT}

19 Understanding the genomic basis of host-parasite adaptation is important for predicting

20 the long-term viability of species and developing successful management practices. However,

21 in wild populations, identifying specific signatures of parasite-driven selection often presents

22 a challenge, as it is difficult to unravel the molecular signatures of selection driven by different,

23 but correlated, environmental factors. Furthermore, separating parasite-mediated selection

24 from similar signatures due to genetic drift and population history can also be difficult.

25 Populations of Atlantic salmon (Salmo salar L.) from northern Europe have pronounced

26 differences in their reactions to the parasitic flatworm Gyrodactylus salaris Malmberg 1957

27 and are therefore a good model to search for specific genomic regions underlying inter-

28 population differences in pathogen response. We used a dense Atlantic salmon SNP array,

29 along with extensive sampling of 43 salmon populations representing the two G. salaris

30 response extremes (extreme susceptibility vs resistant), to screen the salmon genome for

31 signatures of directional selection while attempting to separate the parasite effect from other

32 factors. After combining the results from two independent genome scan analyses, 57 candidate

33 genes potentially under positive selection were identified, out of which 50 were functionally

34 annotated. This candidate gene set was shown to be functionally enriched for lymph node

35 development, focal adhesion genes and anti-viral response, which suggests that the regulation

36 of both innate and acquired immunity might be an important mechanism for salmon response

37 to G. salaris. Overall, our results offer insights into the apparently complex genetic basis of

38 pathogen susceptibility in salmon and highlight methodological challenges for separating the

39 effects of various environmental factors.

40

41 Keywords: Atlantic salmon, genomic adaptation, genome scan, parasite-driven selection,

42 Gyrodactylus salaris 
INTRODUCTION

Parasites act as a strong selective force on natural populations, and given that many of them specialize on a single host species or a few host species, constant arms-races between the hosts and the parasite often occur (Carval and Ferriere, 2010; Kaltz and Shykoff, 1998). The mechanisms of host defence are very diverse and can focus on decreasing parasite fitness and increasing the host's ability to cope with the negative effects of the presence of a parasite (Carval and Ferriere, 2010; Råberg et al., 2007). Several genetic mechanisms of adaptive immune response in vertebrate hosts have been proposed, with earlier studies often focusing on the major histocompatibility complex (MHC) genes and occasionally focusing on other immune-relevant loci (Acevedo-Whitehouse and Cunningham, 2006; Medzhitov, 2007; Sommer, 2005). Being an important link to early vertebrate evolution, teleost fishes have also been the subject of intense research on the mechanisms of both innate and acquired immunity (Zhu et al., 2013). Special interest in understanding the basis of pathogen response had been given to salmonid fish species due to their commercial and recreational importance. For example, in Atlantic salmon, studies of the genetic basis of resistance have been conducted for a number of parasites and pathogens, including salmon lice (Holm et al., 2017; Tadiso et al., 2011), infectious pancreatic necrosis virus (Cepeda et al., 2011; Moen et al., 2015; ReyesLopez et al., 2015), anaemia virus (Moen et al., 2009), and the furunculosis-causing bacterium Aeromonas salmonicida (Dionne et al., 2009).

In this study, we concentrate on the genomic basis of Atlantic salmon adaptation to a particularly dangerous parasite, the monogenean flatworm Gyrodactylus salaris. Atlantic salmon from northern Europe exhibit striking differences in their susceptibility to the parasite. Salmon populations from rivers draining to the Atlantic Ocean and the Barents and White Seas are highly susceptible to G. salaris, with mortality rates following parasite exposure reaching 95\% (Johnsen and Jensen, 1991). Landlocked populations from freshwater lakes Onega and Ladoga, however, are almost completely resistant, with low-level infections being observed in just $1 \%$ of fish (Kuusela et al., 2009). These differences are thought to be due to the phylogeographic histories of the regions, with land-locked salmon having a longer coevolutionary history with the parasite in the eastern freshwater refugium (at least 130,000 years), whereas salmon from the Barents and White Seas were not exposed to G. salaris until recent decades (Kudersky et al., 2003; Kuusela et al., 2009, 2007; Lumme et al., 2016). Despite the potential threat to susceptible salmon populations following G. salaris introduction, the 
77 topic (Gilbey et al., 2006; Kania et al., 2010; Matejusová et al., 2006; Tonteri et al., 2010; 78 Zueva et al., 2014).

79 Understanding range-wide patterns of adaptation is challenging with experimental 80 approaches, but approaches using genome-wide scans to detect signals of strong natural 81 selection can provide means, albeit less direct, for identifying loci underlying local adaptation 82 (Haasl and Payseur, 2016; Oleksyk et al., 2010). A strong selective force, which pathogen 83 presence is likely to be (Fumagalli et al., 2011), is expected to result in an increase in the 84 frequency of advantageous alleles, with a simultaneous reduction in variability in neutral linked sites (Nielsen et al., 2005; Oleksyk et al., 2010). In teleosts, genome scans and candidate gene approaches have been used to test whether genomic regions containing immune-relevant genes exhibit stronger evidence for selection compared to other regions (Pankratz et al., 2010; Tonteri et al., 2008), and to identify the genetic basis of local adaptation linked to a variety of other natural conditions, including water temperature and salinity (Guo et al., 2016; Kusakabe et al., 2017; Limborg et al., 2012b; Nielsen et al., 2009; Vilas et al., 2015). However, identifying genomic signals of selection in response to a particular selective pressure in wild populations can be challenging. One reason for this is that wild populations are constantly exposed to a plethora of different, and often correlated, selective pressures, the relative strengths of which are not always clear and/or may vary. Consequently, it can be challenging to predict which of the selective pressures leaves the most pronounced footprint in the genome and is thus the one that is most likely to be detected by natural selection scans. In addition, genomic signals of the effects of genetic drift (increased divergence and decreased diversity) can be similar to those of natural selection, albeit at a genome-wide scale. In populations with a small effective population size, the identification of signals of selection is even more difficult, as the effect of genetic drift on reduction in allele diversity is more pronounced (Schlötterer, 2003). Population history may further complicate the interpretation of selective signals, as even when subjected to the same selective pressure, populations with different phylogeographic histories, and therefore from different genetic lineages, may follow diverse adaptation paths due to dissimilarity in standing genetic variation (Przeworski et al., 2005). Therefore, a good understanding of population history can help minimize the number of false positives in scans for signals of natural selection.

The abovementioned challenges for identifying the genetic basis of adaptation are of relevance to contemporary Atlantic salmon from northern Europe. Following the retreat of the Scandinavian ice sheet after the last glacial maximum (17,000-15,000 years ago (ya)), different water basins have been colonized at different times and by salmon from various phylogenetic 
111 lineages, resulting in the prolonged isolation of freshwater lakes Ladoga and Onega from

112 Atlantic Ocean salmon and the pronounced genetic divergence between salmon populations in

113 the region at various geographic scales. Northwest Russian lakes Onega and Ladoga were

114 formed first, approximately 13,000 ya (Björck, 1995; Saarnisto and Saarinen, 2001), and were

115 colonized by salmon from an eastern freshwater refugium, which had been previously isolated

116 from an Atlantic Ocean influence for at least 130,000 years (Funder et al., 2002). The Kola

117 Peninsula and White Sea areas were free of ice later than the Russian lakes and were re-

118 colonized by salmon from refugia in the eastern Barents Sea and the south Atlantic Ocean

119 (Asplund et al., 2004; Bourret et al., 2013; Tonteri et al., 2005). As a result, Baltic lineage

120 salmon, including Onega and Ladoga stocks, are genetically highly diverged from the eastern

121 Atlantic Ocean lineage that includes the Barents Sea and the White Sea (Asplund et al., 2004;

122 Bourret et al., 2013; Nilsson et al., 2001; Ozerov et al., 2010; Tonteri et al., 2005). Furthermore,

123 lower effective population sizes, and therefore an increased influence of genetic drift, have

124 resulted in high divergence between the salmon populations from lakes Onega and Ladoga

125 (Ozerov et al., 2010; Tonteri et al., 2007).

126 Given the prolonged isolation of freshwater salmon, it is likely that they have evolved a

127 number of unique traits (in addition to G. salaris resistance) compared to populations in the

128 rest of the range, including variation in the smoltification process (Kiiskinen et al., 2003; Nilsen

129 et al., 2008, 2003) and other physiological functions (Peng et al., 2003) likely resulting from

130 adaptation to a freshwater lifestyle. Water temperature profiles also differ between freshwater

131 northwest Russian lakes and the northern Atlantic Ocean, with both the river water temperature

132 during salmon development and the water temperature of salmon feeding grounds in lakes

133 Ladoga and Onega being generally warmer (Naumenko et al., 1996; Tolstikov and Petrov,

134 2006). While temperature is known to affect metabolic and developmental rates (Brown et al.,

135 2004; Gillooly et al., 2001), it also greatly influences food availability and trophic networks

136 (Winder and Schindler, 2004) as well as pathogen diversity (Adlard et al., 2015; Dionne et al.,

137 2007) and thus is likely to be a strong selective force both in lakes and the ocean. In addition,

138 salmon populations in lakes Ladoga and Onega are relatively small in population size and

139 therefore are likely to be characterized by strong genetic drift (Ozerov et al., 2010; Tonteri et

140 al., 2007). Given the abovementioned, and given the fact that G. salaris susceptibility co-varies

141 with gradients of salinity and temperature in North European salmon populations, it may be

142 challenging to disentangle signals of parasite-mediated selection from other selective forces.

143 We have previously studied the genetic basis of Atlantic salmon adaptation to G. salaris

144 using a genome scan based on 4,631 single nucleotide polymorphisms (SNPs) (Zueva et al., 
145 2014). To address the abovementioned challenges in identifying genetic footprints of selection,

146 we developed and implemented an analysis approach based on multiple tests for selection that

147 involves several combinations of populations varying in geographic location and susceptibility

148 to the parasite. Three genomic regions potentially involved in parasite resistance were

149 identified, as well as three regions possibly related to salinity adaptation. However, the limited

150 number of polymorphic markers, combined with the small number of population samples

151 available, maintains the possibility that some regions under selection may have been missed.

152 In the current study, we address those limitations by genotyping DNA pools on a 220,000 SNP

153 array, and increasing the number of surveyed populations from 12 to 43, allowing for a

154 considerable increase in the resolution of the selection signals. 
MATERIALS AND METHODS

Ethics statement

158

Samples used in this study were obtained according to relevant national legislations and were described previously (Ozerov et al., 2012, 2010; Zueva et al., 2014).

\section{Sampled populations}

Atlantic salmon from 44 north European populations were initially included in the study. Sample sizes per location varied from 23 (Lizma river) to 326 (Tenojoki_1 river), totalling 2,438 individuals (Table 1, Figure 1). Most samples represented juveniles collected between 1997 and 2005 via electrofishing, where tissue was stored in 95\% ethanol (see Ozerov et al. 2010, 2012 for details) except for the Näätämö River and two sub-populations from the Teno River that originated from air-dried scales collected from adults during their spawning migration (Aykanat et al., 2015; Pritchard et al., 2016). Earlier research has indicated that the vast majority of these population exhibit temporarily stable population structure (Ozerov et al., 2013).

Sample preparation and population pooling

Total genomic DNA was extracted using one of several methods including NucleoSpin ${ }^{\circledR}$ Tissue (Macherey Nagel) protocol, salt extraction protocol (Aljanabi and Martinez, 1997), vacuum extraction with glass beads (as in Elphinstone et al. 2003), or QIAamp DNA mini kit (Qiagen). DNA extraction and sample pooling for Tenojoki_1, Tenojoki_2 and Näätämö rivers were described in Aykanat et al. (2015) and Pritchard et al.

178 (2016). Individual DNA samples from remaining 41 populations extracted for previous studies 179 (e.g. Tonteri et al. 2007; Ozerov et al. 2010; Zueva et al. 2014), were subjectively assessed for degradation by electrophoretic separation on a $1 \%$ agarose gel. Samples showing excessive signs of degradation (low molecular weight DNA) were re-extracted with QIAamp DNA mini kit (Qiagen) (618 samples). The concentration of individual DNA samples was measured using a Qubit 2.0 fluorometer and Qubit dsDNA HS Assay kit (Life Technologies), and adjusted to a final concentration of $10 \mathrm{ng} / \mathrm{ul}$. Equal amounts of DNA from all individuals from the same population were combined to make a population pool, with four technical replicates per population, i.e., $41 \times 4=164$ pools in total. The final concentration of each pool was measured with Qubit to verify that it was $10 \pm 0.5 \mathrm{ng} / \mathrm{ul}$. 
190 For each pool, allele intensities were obtained for 220,000 SNPs genotyped on a custom

191 Affymetrix Axiom array (Life Technologies) according to the manufacturer's instructions (see

192 Barson et al. 2015 for array details) at the Centre for Integrative Genetics (CIGENE, Norway).

193 These data were subjected to a series of manipulations and quality checking steps. First, the

194 relative intensities of the B allele were calculated and corrected for unequal allele

195 representation using a polynomial specific probe correction algorithm, PPC (Brohede et al.,

196 2005). Salmon ( $n=610)$ previously genotyped as individuals and allelotyped in pools were used

197 for PPC correction (Supplementary material S_script1). SNP loci were removed from the data

198 set if they, (i) did not include all 3 possible genotypes (AA, AB and $\mathrm{BB}$ ) in the reference sample

199 of 610 individuals, (ii) could be affected by a known off-target variant, (iii) deviated from HWE

200 with $\mathrm{P}<0.00001$, or (iv) had a minor allele frequency across all populations less than 0.05

201 (Supplementary material S_script2). SNPs were tested for deviation from Hardy-Weinberg

202 equilibrium using individual genotypes of samples from the mainstem Tenojoki population

203 (data as in Pritchard et al., 2016). Strong deviation from HWE may indicate genotype calling

204 errors (e.g. homozygotes and heterozygotes are both being called as homozygotes), and a

205 significance level of 0.00001 was chosen in order to primarily exclude SNPs that deviate from

206 HWE due to technical issues. Furthermore, for every SNP, we tested the variability of allele B

207 frequencies over four pooling replicates by comparing sets of SNPs with the highest standard

208 deviation (SD) over replicas between all populations (20\% of most variable SNPs for each

209 population). None of the SNPs had high SD over replicates in all the populations, and therefore,

210 none of the SNPs were filtered out during this step (Supplementary material S_script 3).

211 Population Chapoma, however, was excluded due to a high number of SNPs with high SD over

212 genotyping replicas (3\% of all SNPs had SD > 0.1 in Chapoma, whereas for the other

213 populations, this number was approximately 0.4\%; Supplementary material S_script 3). For

214 the remaining populations, the arithmetic mean of allele B frequencies for each SNP was

215 calculated using allele frequencies falling within $25 \%$ and $75 \%$ quantiles of the original

216 frequency distribution between four genotyping replicates (Supplementary material S_script 4,

217 5). After quality control, 197,431 SNPs and 43 populations were retained for further analyses.

Salmon genome annotation

Annotations for the Atlantic salmon genome were obtained via R package Ssa.RefSeq.db 
223 (https://www.ncbi.nlm.nih.gov/genome/369?genome_assembly_id=248466), and Gene

224 Ontology annotations are assigned to genes by blasting the predicted coding sequences against

225

226

227

228

229

230

231

232

233

234

235

236

237

238

239

240

241

242

243

244

245

246

247

248

249

250

251

252

253

254

\section{Population genetics and outlier locus detection}

Principal component analysis (PCA) was performed to assess the basic population genetic structure using the prcomp algorithm within the built-in 'stats' package within the R-3.4.0 environment ( $\mathrm{R}$ Core Team, 2016) (Supplementary material S_script 6). To identify the genome regions potentially affected by signals of selection, we used two independent methods that are suitable for implementation with pooled SNP data, and primarily concentrated on SNPs found to be outliers by both approaches.

Bayenv, implemented in the Bayenv2.0 software, is a Bayesian method that can be used to identify SNPs with unusually large allele frequency differentiation after accounting for population history and gene flow (Günther and Coop, 2013). As we were interested in selection signals that were common across populations within each geographical region, we treated the three geographic regions (Barents \& White Seas, Lake Ladoga, and Lake Onega) as populations, while original populations within a region were treated as individuals. Allele frequencies per SNP per region were then calculated as the arithmetic mean of the population allele frequencies. Allele frequencies were converted to allele counts, required for Bayenv2.0 input files, based on the total number of individuals across all populations in a region (Supplementary material S_script7.1). Three pair-wise comparisons were performed: Barents \& White Seas vs. Ladoga lake, Barents \& White Seas vs. Onega lake, and Ladoga lake vs. 
255 Onega lake. Using PLINK software (Purcell et al., 2007) we first identified SNPs with no

256 linkage disequilibrium between them, and a random subset of these SNPs was used to compute

257

258

259

260

261

262

263

264

265

266

267

268

269

270

271

272

273

274

275

276

277

278

279

280

281

282

283

284

285

286

287

288 a covariance matrix between the populations. We checked the convergence of matrices built using different numbers of random SNPs and the influence of the iteration number. As a result, covariance matrices were built using 50,000 SNPs and 100,000 iterations, which proved to be both sufficient and computationally effective. During the next step, Bayenv2.0 calculates a population differentiation statistic called $\mathrm{X}^{\mathrm{T}} \mathrm{X}$, analogous to the well-known $F_{\mathrm{ST}}$, but based on standardized allele frequencies that were derived to account for population structure. $\mathrm{X}^{\mathrm{T}} \mathrm{X}$ was calculated using 10,000 iterations and was used to identify loci that are more differentiated than expected under pure drift between populations (Günther and Coop, 2013). The software does not provide significance estimations for deviation from the null distribution. Therefore, a custom cut-off at the upper $0.005 \%$ quantile of the statistical distribution was applied to determine possible SNP outliers (Supplementary material S_script7.2). Next, we compared the results from the three pair-wise comparisons, focusing on genomic regions harbouring peaks of SNPs with elevated $\mathrm{X}^{\mathrm{T}} \mathrm{X}$ statistics in both the Barents \& White Seas vs. Ladoga lake and the Barents \& White Seas vs. Onega lake comparisons, but absent from the Ladoga lake vs. Onega lake comparison. Populations in landlocked lakes have been isolated from each other for a long period of time, and this approach allows us to exclude genomic regions that are likely to exhibit elevated levels of differentiation due to genetic drift rather than directional selection. Further, we identified genes that contained outlier SNPs within their margine using bedtools software and the procedure described above. Only genes that had outliers in both Barents \& White Seas vs. Ladoga lake and Barents \& White Seas vs. Onega lake tests were considered to be candidates (see Results).

A second method used to detect outlier loci was the Bayesian approach implemented in the BayeScan2.1 software (Foll and Gaggiotti, 2008). This approach allows direct estimation of the posterior probability of a given locus to be under the effect of selection by defining two alternative models, one that includes the effect of selection and another that excludes it, and testing their respective posterior probabilities using a MCMC approach. The method uses population-specific and locus-specific components of $F_{\mathrm{ST}}$ coefficients and has been suggested to be robust when dealing with complex demographic scenarios for neutral genetic differentiation (Foll and Gaggiotti, 2008). The same logic as for Bayenv2 was applied: we performed three pair-wise comparisons, where geographic regions were treated as populations and original populations were treated as individuals. Calculations were performed under the default parameters. Outlier SNPs were identified with a false discovery rate of 0.05 , and 
respective genes were assigned to each outlier SNP using bedtools. The final set of candidate genes under selection was obtained by identifying genes that were detected by both Barents \&

291 White Seas vs. Ladoga lake and Barents \& White Seas vs. Onega lake comparisons, but were not present among outliers in the Ladoga lake vs. Onega lake test. Genes present both in

293 Bayenv2.0 and BayeScan2.1-based candidate gene sets were further considered as candidate 294 genes potentially affected by selection (Supplementary material S_script8).

We also considered single SNPs with the most pronounced levels of genetic differentiation based on both Bayenv2.0 and BayeScan2.1 approaches as candidates, initially regardless of the overlap between the tests or population comparisons. For each of the tests, the 50 SNPs with the most extreme statistics (the highest $\mathrm{X}^{\mathrm{T}} \mathrm{X}$ for Bayenv2.0, and the lowest q-values for BayeScan2.1) were selected, and associated genes harbouring the SNPs were retrieved using

300 the bedtools. These gene sets were then compared between the Bayenv2.0 and BayeScan2.1

301 approaches and between the Barents \& White Seas vs. Ladoga lake, Barents \& White Seas vs.

302 Onega lake and Ladoga lake vs. Onega lake pair-wise comparisons.

303 Functional annotation and functional enrichment test

304 Annotations of all SNPs to specific gene ontology (GO) terms (Ashburner et al., 2000) 305 were obtained via the Ssa.RefSeq.db package. To determine whether the set of identified 306 candidate genes (see Results) was significantly enriched or depleted for particular GO terms, 307 we performed an enrichment test, implemented in the topGO package in R, using the weight01 308 algorithm and the list of all Atlantic salmon genes that contained SNPs from the SNP array as 309 a reference (Supplementary material S_script9). 


\section{RESULTS}

311

312

313

314

315

316

317

318

319

320

321

322

323

324

325

326

327

328

329

330

331

332

333

334

335

336

337

338

339

340

341

\section{Population genetic structure}

Populations from different geographic regions clustered in distinct groups based on principal component analysis. The first PC explained $42 \%$ of the variance and separated the Barents \& White Seas salmon populations from the freshwater lakes. The second component, explaining 9\% of variance, separated the Ladoga and Onega lakes (Figure 2).

Detecting signals of selection

$\mathrm{X}^{\mathrm{T}} \mathrm{X}$ statistics for each SNP for each of the Barents \& White Seas vs. Ladoga lake, Barents $\&$ White Seas vs. Onega lake and Ladoga lake vs. Onega lake pair-wise tests and $0.005 \%$ upper quantile outliers were estimated using Bayenv2 and are presented in Table_S1. Altogether, 118 candidate outlier genes were detected in both Barents \& White Seas vs. Ladoga lake and Barents \& White Seas vs. Onega lake comparisons, but not from the Ladoga lake vs. Onega lake test after mapping outlier SNPs to specific genes (Figure 3, Table_S2).

Outlier SNPs detected using BayeScan2.1 for each of the Barents \& White Seas vs. Ladoga lake, Barents \& White Seas vs. Onega lake and Ladoga lake vs. Onega lake pair-wise tests with a q-value false discovery threshold of 0.05 are presented in Table_S3. Once SNPs were mapped to the genes, 167 candidate genes harbouring SNPs exhibiting signals consistent with positive selection were shared between the Barents \& White Seas vs. Ladoga lake and Barents \& White Seas vs. Onega lake tests (Figure 3, Table_S4).

Fifty seven genes with outlier SNPs on 24 chromosomes were common for both the Bayenv2 and BayeScan2.1 analysis approaches and were therefore considered as the most promising candidates to be affected by positive selection that distinguishes salmon originating from the Atlantic Ocean from those originating from freshwater lakes (Table 2, Table_S5).

When the most highly genetically differentiated SNPs from both Bayenv2.0 and BayeScan2.1 tests were considered, approximately half of the yielded genes were similar between both approaches (Table_S6). However, the overlap between the Barents \& White Seas vs. Ladoga lake and Barents \& White Seas vs. Onega lake comparisons was less pronounced. Only one gene, serine/threonine-protein phosphatase regulatory subunit, was among the most differentiated based on both Bayenv2.0 and BayeScan2.1 and for both the Barents \& White Seas vs. Ladoga lake and Barents \& White Seas vs. Onega lake comparisons (Table 2).

\section{Functional annotation}


Using the Ssa.RefSeq.db package and the annotation procedure described above, out of 343 the 48,785 protein-coding genes reported for Atlantic salmon, 30,560 genes had a SNP within 344 their margin, and 23,850 of these genes were annotated with GO terms (Table_S7). From a 345 candidate set of 57 genes, 50 genes were annotated (Table_S7). Enrichment analysis retrieved 346 several GO terms that were significantly overrepresented in the set of 50 annotated candidate 347 genes. These included three biological processes with significance levels less than 0.01: 348 response to arsenic containing substance (GO: 0046685), lymph node development (GO:00 349 48535), and response to virus (GO: 0009615). The only enriched cellular components was 350 microtubule organizing center (GO:0005815). Finally, the most highly enriched molecular 351 function GO terms were phospholipase activator activity (GO: 0016004), vinculin activity 352 (GO: 0017166), and phosphatidylinositol phospholipase C activity (GO: 0004435) (Table_S5, 353 S8). 
In this study, we utilized an extensive sample of 43 anadromous and landlocked salmon populations and almost 200,000 SNPs to investigate the genomic basis of differences in susceptibility to the parasite Gyrodactylus salaris observed in north European Atlantic salmon populations. By combining results from different outlier tests, we established a set of 57 candidate genes potentially associated with parasite tolerance/susceptibility.

\section{Evidence of immune related functions of candidate genes}

Several GO terms related to both innate and acquired immunity were enriched amongst the 57 candidate genes.

The most significantly enriched biological process term was response to arsenic-containing substance, GO:0046685, and along with another significant term, response to virus (GO:0009615), it was associated with the interferon-induced GTP-binding protein Mx-like gene. There are several copies of the mx (myxovirus)-like gene on chromosome 25, and three of them are included in the set of 57 candidate genes in our analysis (Table 2). Mx genes are induced during virus infection as a part of interferon-mediated innate immune response, and are active against a wide range of DNA and RNA viruses (Mitchell et al., 2013). The same set of genes was recently found to be highly diverged between salmon lineages from the Atlantic Ocean and the Finnmark region, which includes the Barents Sea clade (Kjærner-Semb et al., 2016). Our results suggest this genome region is under selection in Atlantic salmon more broadly as our study included populations from regions not studied previously, e.g. land-locked populations.

The third significantly enriched biological process term was lymph node development, GO:0048535. Earlier research on a number of genes with this GO term provides support for this process potentially being important in Gyrodactylus resistance in Atlantic salmon. Lymph nodes are essential part of the mammalian adaptive immune system as they are involved in lymph filtering and circulation, and are a place of residence for leukocytes including $\mathrm{B}$ and $\mathrm{T}$ lymphocytes. The lymphoid system of teleosts lacks lymph nodes, but include organs with similar functions such as lymphatic vessels, thymus, head kidney (considered an ortholog of mammalian bone marrow) and spleen (Hedrick et al., 2013; Sunyer, 2013). T-lymphocytes, developing and maturing in the thymus, as well as interleukin signalling pathways in fishes also resemble those of mammals (Nakanishi et al., 2015; Zapata et al., 2006). One of the genes associated with the lymph node GO term is the T-cell leukemia homeobox protein 1 (TLX1) - 
like gene, involved in mammalian spleen development (Yamamoto et al., 1995). TLX1 is also expressed during fish spleen development and presumably contributes to a supportive microenvironment for the maturation of lymphocytes, which appear in fish spleen after they become present in thymus and kidney (Boehm et al., 2012; Li et al., 2017). Another associated gene, nuclear receptor ROR-alpha-like gene $(R O R \alpha)$, has diverse biological functions including regulation of glucose and free fatty acid metabolism (Kadiri et al., 2015) and is also an important pro-inflammatory agent participating in regulation of inflammation cytokines (Sadeghi et al., 2015; Sun et al., 2015) and modulation essential for inflammation T-helper lymphocytes (Th-17) (Yang et al., 2008). In teleosts, ROR $\alpha$, along with another transcription factor $R O R \gamma$, regulate expression of pro-inflammatory interleukins-17 (IL-17). IL-17 members have been identified in several fish species including Atlantic salmon, and are reported to play crucial roles in host defense against microbial organisms (Chi et al., 2016; Kumari et al., 2009).

Involvement of the candidate gene set in immune response was further emphasized by the enriched cellular component and molecular function GO terms: microtubule organizing center, vinculin binding, and phospholipase activity; united by their association to cytoskeleton, formation of focal and cell-cell adhesions and cell signaling. Reorganization of leukocytes' membrane, required for generating and maintaining immune response, depends on drastic changes of microtubule organizing center and involves the segregation of membrane and intracellular signaling proteins (Sancho et al., 2002). Talin, one of the proteins associated with the microtubule organizing center (MOC) GO term (Table_S5), binds trans-membrane receptors to actin cell cytoskeleton and is crucial during phagocytosis in amoeba and mammals (Freeman and Grinstein, 2014; Lim et al., 2007), as well as during adhesion of natural killer cells and T-lymphocytes to the extra-cellular matrix and target cells (Mace et al., 2009; Stanton et al., 2014). Talin-integrin complex is stabilized with the help of vinculin, and is dependent on activating of tyrosine phosporylation, as well as activity of phosphatidylinositol 3-kinase (PI3K) and phospholipase C. Altogether two genes from the candidate gene set have phospholipase A and phospholipase C- activity. Phospholipases, while involved in a number of signalling pathways, are known to have an important role in signal transduction in leukocytes, e.g., natural killer cells (Caraux et al., 2017), and have a pronounced role in inflammation processes (Boilard et al., 2010). Most of the abovementioned studies were conducted using mammalian models, but teleosts express a variety of similar interleukins, integrin complexes, and signalling pathways involved in immune regulation, for example IL21,22 and PI3K-signalling (Costa et al., 2013; Wang et al., 2011), immunoreceptors that contain tyrosine-based activation motifs (ITAMs) (Blank et al., 2009), as well as CR3 integrins 
that require actin-activation (Lillico et al., 2017; Mikrou et al., 2009). Toll-signaling, another vital part of immune signaling, is also present in teleost fishes (Hanington et al., 2009; Rebl et al., 2010). One of the candidate genes, sphingomyelin phosphodiesterase 3 , is involved in lipid metabolism and was shown to regulate Toll-like receptors signalling in mice macrophages (Heinz et al., 2015). Granulin, one of the co-factors for Toll-like receptors (Park et al., 2011), promotes host cell proliferation when excreted by liver flukes (Bansal et al., 2017; Smout et al., 2009), and it is known that an extensive skin and mucus proliferation is one of the consequences of $G$. salaris infection in susceptible Atlantic salmon (see below).

Three of the candidate genes harbour non-synonymous (missense) outlier SNPs, which implies that they may result in a change of protein structure and therefore possibly protein function (Table2, Table S5). Linking these genes to immune response processes is not straightforward, as they are involved in a number of cellular processes. However, NAGPA, playing part in lysosomal activity, is known to be important in maturation of dendritic cells required for T-cells stimulation (Trombetta et al., 2003). RNA helicases from the DEAD/H family, to which another gene, DNA helicase $d d x 11$, belongs to, have been associated with innate immunity and response to viruses in humans (Oshiumi et al., 2010; Schröder, 2011) and salmonids (Castro et al., 2013; Krasnov et al., 2011). A link with pathogen-induced signalling in innate immune system was also identifiable for the third gene, TBC1D5, which is involved in induction and regulation of autophagy (Faure and Lafont, 2013). Taken together, these results suggest involvement of the candidate gene set in cell-signalling during both innate and adaptive immune response, and the mentioned genes are thus promising candidates for future research.

The candidate gene set described above was formed based on criteria of overlap between the Bayenv2.0 and BayeScan2.1 results and overlap between the Barents \& White Seas vs. Ladoga lake and Barents \& White Seas vs. Onega lake pair-wise comparisons. However, we also looked for the genes harbouring the most significant SNPs regardless of the overlaps between the analysis approaches and pair-wise comparisons. The Bayenv2.0 and BayeScan2.1 tests independently resulted in comparable sets of SNPs with high differentiation, with approximately $50 \%$ of the related genes being similar between the tests. Within the results of both Bayenv2.0 and BayeScan2.1 tests, there were obvious differences between the pair-wise comparisons, as almost none of the genes overlapped between the Barents \& White Seas vs. Ladoga lake, Barents \& White Seas vs. Onega lake, or Ladoga lake vs. Onega lake pair-wise comparisons. Only one gene from the candidate gene set described above, the serine/threonineprotein phosphatase $2 \mathrm{~A}(p p 2 A) 56 \mathrm{kDa}$ regulatory subunit gamma -like gene, emerged in both 
the Barents \& White Seas vs. Ladoga lake and Barents \& White Seas vs. Onega lake comparisons (but not in the Ladoga lake vs. Onega lake comparison). PP2A is the major phosphatase for microtubule-associated proteins (Abraham et al., 2000; Watkins et al., 2012) and is abundant in mammalian lymphocytes (Chuang et al., 2000). It was suggested as an immune relevant gene in common carp (Abdelkhalek et al., 2014), and is thus a promising gene for future research on immune regulation in fishes.

Overall, these findings are consistent with the idea of $G$. salaris tolerance/susceptibility differences observed between landlocked and Atlantic Ocean salmon populations being linked to natural selection acting on the regulatory mechanisms of both innate and adaptive immune systems. To further test this hypothesis and to strengthen the candidacy of reported genes several directions for future research could be suggested. First, the expression profiles for the candidate genes can be compared by parasite challenge experiments using individuals from susceptible and resistant populations in a controlled laboratory environment, e.g. using qPCR. This approach was fruitful in gene expression experiments featuring Atlantic salmon and G. salaris, when up-regulation of potentially immune relevant myeloid leukemia differentiation protein was detected in susceptible salmon (Matejusová et al., 2006); as well as in number of other studies challenging salmonids with various pathogens (Haarder et al., 2013; Krasnov et al., 2012). Furthermore, for candidate genes with presumed regulatory function, expression of downstream regulatory targets could also be quantified, and for candidate genes with presumed enzymatic activity (effectors) biochemical assays could be used to quantify corresponding protein activity. Another possibility for follow-up research is to concentrate on G. salaris susceptible salmon populations that due to continuous re-stocking survive the infection: Keret' river in the White Sea (Kuusela et al., 2009), and Drammen system in Norway (Bakke et al., 1990). Notably, genetic composition of Keret' river salmon was suggested to have changed over the years in response to parasite load (Artamonova et al., 2008). Utilizing a dense SNP array and a knowledge of candidate genes, it is possible to test hypotheses of the precise targets of this temporal change.

\section{Comparison with previous studies}

One of the genes from the candidate genes set, coding for an adhesion $\mathrm{G}$ protein-coupled receptor L2 (adgrl2), is located within the G. salaris - related region on chromosome 10 detected in our previous study (Zueva et al., 2014). G protein-coupled receptors are involved in a plethora of signal-transduction pathways, including T-cell signaling (Goetzl et al., 2004; 
ADGRL-type receptors, at least in mammals, are crucial for functioning of nervous and

491

492

493

494

495

496

497

498

499

500

501

502

503

504

505

506

507

508

509

510

511

512

513

514

515

516

517

518

519

520

521

522

523

cardiovascular systems, but their possible involvement in teleost immune system is not yet clear.

Taken together, genomic regions associated with G. salaris presence based on Zueva et al. (2014) were clustered into two functional groups; one of the groups included genes involved in $\mathrm{T}$ cell activation and the other included genes involved in the synthesis and elongation of fatty acids, which are known to moderate inflammation and act as anti-pathogen agents (Calder, 2001; Carballeira, 2008; Harbige, 2003). Regulation of T-lymphocytes is part of adaptive immunity, whereas lipid metabolism and macrophage activation are part of innate immunity. Experimental studies on Atlantic salmon response to G. salaris are limited, and it is hard to predict the exact mechanisms that form the foundation of resistance and/or tolerance to the parasite. It was demonstrated, however, that highly susceptible salmon from the east Atlantic responded to G. salaris exposure by an elevated production of interleukin-1b and interferongamma cytokines, which enhance the proliferation of the epithelial and mucous cells that the parasite feeds on. Less susceptible Baltic salmon responded to the parasite with delay and by the activation of genes that did not result in mucus proliferation. It was suggested that by regulating the initial stages of inflammation, and consequently, mucus production, Baltic salmon are able to control parasite abundance by starving it (Kania et al., 2010; Lindenstrom et al., 2006). An acquired immune response generally takes more time to develop and initiate, and given that G. salaris presence can result in the rapid decline of infected fish (Bakke et al., 1990, 2004), it is feasible that the defence mechanisms against this parasite species are focused, at least partly, around the innate immune system.

The overall functional patterns of the detected gene sets are similar between the previous and current studies, and the limited overlap between the candidate genes and genomic regions is not unexpected. Most obviously, the current study is based on a qualitatively greater number of SNPs, with the average SNP density being one SNP per 0.018 mega bases $(\mathrm{Mb})$ as opposed to one SNP per $0.5 \mathrm{Mb}$ in the previous study. Consequently, previous regions of elevated $F_{\mathrm{ST}}$ are masked by much more narrow and abundant regions of both elevated and reduced genetic differentiation that have been detected in current study. The low SNP coverage in Zueva et al. 2014 also complicates the result comparison itself, as whether we find overlap or not depends on the distance used to assign SNPs to genes. In addition, the annotation of the salmon genome has improved rapidly in recent years following publication of the Atlantic salmon genome sequence (Lien et al., 2016). Indeed, a number of significant SNPs were excluded from enrichment analyses in the previous study due to a lack of functional annotation. Furthermore, 
524 the two studies differ in the methods used for identifying genomic regions of selection and in

525 the analysis design used to select the final candidate gene sets. In addition, while there was 526 only one overlap between the current results and the genomic regions identified based on a combination of all four tests in the previous study, there were common genes when considering the tests used in Zueva et al. (2014) one at a time. For example, Design 4 (single loci outlier test) from Zueva et al. (2014) detected one gene that was also present in the current candidate gene set: $w w c 1$, participating in phosphorylation; Design 1 (reduced diversity in freshwater lakes) detected a $R O R \alpha$-like gene described previously, and a chromobox protein homolog 7 that among other functions modulated $\mathrm{CD}^{+} \mathrm{T}$ cell apoptosis in mammals ( $\mathrm{Li}$ et al., 2014). Overall, it is encouraging that regardless of the chosen strategy, both the current and previous studies resulted in identifying candidate regions that share functional characteristics.

The genomic basis of tolerance to G. salaris has also been studied using a QTL approach by back-crossing the parasite susceptible Scottish salmon with parasite-tolerant Baltic salmon, and several microsatellites associated with $G$. salaris tolerance have been identified (Gilbey et al., 2006). These associations represented entire linkage groups, and a direct comparison of the results should be done with caution since there can be inconsistencies in linkage group names between the SALMAP project, used by Gilbey and co-authors, and the current Atlantic salmon genome build. Nevertheless, linkage groups 1, 4, 5, 6, 9, 13, 18 and 25 were suggested by both results, and altogether, our findings are consistent with the idea of polygenic control for both innate and acquired $G$. salaris resistance as suggested by Gilbey and co-authors.

\section{Interpreting the results: challenges and perspectives}

Biological perspective: the challenge of correlated environmental traits.

The results of this study highlight several of the challenges of using a genome-scan approach to identify loci associated with a specific phenotypic trait, even when dramatic differences in the trait exist between replicated populations. These challenges can be both environmental and genetic in nature. As noted earlier, separating signals of selection on correlated environmental and phenotypic traits can be challenging when working at the between-population level. In the case of Atlantic salmon from northern Europe, these traits include parasite presence/absence, salinity of the water basin that the fish migrates to, water temperature in both the home rivers and on the feeding grounds, as well as hypothetical differences in fish diet in marine and freshwater environments. Given the potential drastic 
very pronounced footprint of selection in the salmon genome, and our analyses were designed to focus on this assumption. However, we cannot exclude the possibility that the observed signals of selection are partly due to other selective forces in addition to the effects of the parasite. For example, apart from immune function, actin-based cytoskeleton was shown to play a role in osmotic regulation of $\mathrm{K}^{+} / \mathrm{Na}^{+} / 2 \mathrm{Cl}$ cotransporters (Flatman, 2002; Lionetto and Schettino, 2006). Cation-chloride cotransporters, such as the $\mathrm{K}^{+} / \mathrm{Na}^{+} / 2 \mathrm{Cl}$ cotransporter, are known to be associated with salinity adaptation in a number of fish species, including the brackish medaka (Oryzias dancena) (Kang et al., 2010), Mozambique tilapia, Oreochromis mossambicus, (Hiroi et al., 2008) and mummichog, Fundulus heteroclitus (Hoffmann et al., 2002). Interleukins, immune signal molecules associated with a number of genes desribed above, have also shown signals of divergent selection between anadromous and landlocked brown trout (Limborg et al., 2012a; Narum et al., 2011). On the other hand, a number of studies have documented an increase of phagosystosis, alterations in antimicrobial enzyme lysozyme levels, as well as change in IgM levels in response to salinity alteration, indicating strong effect of salinity on innate and adaptive immune systems of teleosts (Bowden, 2008; Makrinos and Bowden, 2016). A genetic issue that may disguise the target of selection is gene pleiotropy: when a particular gene has multiple functions, it may not be clear which specific function has resulted in a gene or a genomic region exhibiting signatures of selection. Furthermore, pleiotropic effects may constrain selection on a particular trait, when the genetic response to selection on one trait is limited by selection on other correlated traits controlled by the gene (Orr, 2000; Wagner and Zhang, 2011). The level of gene pleiotropy has been shown to be negatively correlated with variability in gene expression in response to environmental change and is thus an evolutionary constraint (Papakostas et al., 2014). Many candidate genes from our study are involved in a number of other processes apart from immunity. For example, serine/threonine-protein phosphatase $2 \mathrm{~A}$ and $2 \mathrm{~B}$ are also involved in osmoregulation (Nakamura et al., 1993; Shiozaki and Russell, 1995), while nuclear receptor ror-alpha is associated with circadian clock (Yang et al., 2006). If the basis of salmon response to G. salaris is controlled by several genes with multiple additional functions, the genomic signals of selection on these genes may be less pronounced and thus more difficult to identify and/or interpret.

Methodological perspective: power of genome scans

The candidate gene set identified in this study is based on the overlapping results of two approaches for identifying signals of selection, implemented in the Bayenv2.0 and 
592 BayeScan2.1 software. A focus on loci identified as outliers in several tests has been applied

593 in a number of studies to strengthen the candidacy of identified loci targeted by selection and 594 to reduce type I errors (Oleksyk et al., 2008; Vasemägi et al., 2005). Such an approach may, 595 however, reduce the chances of identifying loci under weak selection (Whitlock and Lotterhos, 596 2015). Both approaches implemented in the current study suggested a large number of "outlier" 597 SNPs and associated genes, but just under half were common between the tests (57 genes out 598 of more than 115 in each test). These tests are based on quantifying population differentiation 599 in terms of $F_{\mathrm{ST}}$ or related measures and use different approaches to correct for neutral 600 population structure (Hoban et al., 2016); thus, some of the resulting outliers might be an 601 outcome of pronounced genetic drift and restricted gene flow (Bierne et al., 2011; Oleksyk et al., 2010), explaining the lack of full overlap between the identified regions of selection.

One caveat that is relevant for our study, and indeed all outlier analyses conducted in Atlantic salmon thus far is that due to not complete genome rediploidization approximately $10 \%$ of Atlantic salmon genome retain residual tetrasomy (Lien et al., 2016). Because of this, SNPs from this portion of the genome are not represented in the SNP array for technical reasons. Therefore potentially important genes residing in those regions might not have been detected. Another factor that could potentially affect outlier identification is ascertainment bias (Lachance and Tishkoff 2013) stemming from the fact that SNPs included in the array were based on their polymorphism in Norwegian aquaculture salmon from the Atlantic lineage. However, the relative levels of population genetic diversity and divergence estimated in the present study are in line with previous assessments using a different marker type (microsatellites: Ozerov et al., 2010; Tonteri et al., 2009). Further, all comparisons are between multiple populations from lineages other than the Atlantic lineage. Thus, it is unlikely that potential SNP ascertainment bias has had a large effect on the results.

\section{CONCLUSIONS}

616 Overall, our results suggest an apparently complex genetic basis of Gyrodactylus salaris susceptibility and resistance in Atlantic salmon and highlight some methodological challenges for separating the effects of various environmental factors. Despite these challenges, it appears that the regulation of both innate and acquired immunity are important mechanisms in the response of Atlantic salmon to G. salaris and this study provides a number of promising candidate genes for future studies.

\section{ACKNOWLEDGMENTS}

We would like to express our gratitude to Jan Nilsson, Jaakko Erkinaro, Anti Vasemägi, 
626 Mikhail Ozerov and Anni Tonteri for performing some of the DNA extractions more than 10

627 years ago. We are grateful to Fabian Grammes for his help with the Ssa.RefSeq.db package.

628 Special thanks to Victoria Pritchard and Matthieu Bruneaux for analytical assistance and to

629 the reviewers for their constructive comments that improved the manuscript. This research

630 has been funded by the Academy of Finland (grants 302873 and 284941).

631

632 AUTHOR CONTRIBUTIONS

633 Conceived and designed the experiments: KJZ, CRP. Performed the experiments: KJZ,

634 MPK. Analyzed the data: KJZ. Contributed reagents/materials/analysis tools: AEV, JL,

635 MPK. Wrote the paper: KJZ, CRP. Commented on the manuscript: MPK, JL, AEV.

636

637

DATA ARCHIVING STATEMENT

638 Raw data and code used in analyses are archived in the Dryad Digital Repository:

639 (http://dx.doi.org/..., to be updated)

640 


\section{REFERENCES}

Abdelkhalek, N.K., Komiya, A., Kato-Unoki, Y., Spmamoto, T., Nakao, M., 2014. Identification of Immune Relevant Genes Using Expressed Sequence Tags (ESTs) in Common carp (Caprinus caprio) Gills. J. Fac. Agric. Kyushu Univ. 59, 109-116.

Abraham, D., Podar, K., Pacher, M., Kubicek, M., Welzel, N., Hemmings, B.A., Dilworth, S.M., Mischak, H., Kolch, W., Baccarini, M., 2000. Raf-1-associated protein phosphatase 2A as a positive regulator of kinase activation. J. Biol. Chem. 275, 2230022304. doi:10.1074/jbc.M003259200

Acevedo-Whitehouse, K., Cunningham, A.A., 2006. Is MHC enough for understanding wildlife immunogenetics? TRENDS Ecol. Evol. 21, 433-438.

Adlard, R.D., Miller, T.L., Smit, N.J., 2015. The butterfly effect: parasite diversity, environment, and emerging disease in aquatic wildlife. Trends Parasitol. 31, 160-166. doi:10.1016/j.pt.2014.11.001

Aljanabi, S.M., Martinez, I., 1997. Universal and rapid salt-extraction of high quality genomic DNA for PCR-based techniques. Nucleic Acids Res. 25, 4692-4693.

Artamonova, V.S., Khaimina, O. V., Makhrov, A.A., Shirokov, V.A., Shulman, B.S., Shurov, I.L., 2008. Evolutionary consequences of parasite invasion: A case study of Atlantic salmon Salmo salar L. Dokl. Biol. Sci. 423, 412-415. doi:10.1134/S0012496608060136 Ashburner, M., Ball, C.A., Blake, J.A., Botstein, D., Butler, H., Cherry, J.M., Davis, A.P., Dolinski, K., Dwight, S.S., Eppig, J.T., Harris, M.A., Hill, D.P., Issel-Tarver, L., Kasarskis, A., Lewis, S., Matese, J.C., Richardson, J.E., Ringwald, M., Rubin, G.M., Sherlock, G., 2000. Gene Ontology: tool for the unification of biology. Nat. Genet. 25, 25-29. doi:10.1038/75556

Asplund, T., Veselov, A., Primmer, C.R., Bakhmet, I., Potutkin, A., Titov, S., Zubchenko, A., Studenov, I., Kaluzchin, S., Lumme, J., 2004. Geographical structure and postglacial history of mtDNA haplotype variation in Atlantic salmon (Salmo salar L.) among rivers of the White and Barents Sea basins. Ann. Zool. Fennici 41, 465-475.

Aykanat, T., Johnston, S.E., Orell, P., Niemelä, E., Erkinaro, J., Primmer, C.R., 2015. Low but significant genetic differentiation underlies biologically meaningful phenotypic divergence in a large Atlantic salmon population. Mol. Ecol. 24, 5158-5174. doi: $10.1111 / \mathrm{mec} .13383$

Bakke, T.A., Jansen, P.A., Hansen, L.P., 1990. Differences in the host resistance of Atlantic salmon . Salmo salar L ., stocks to the monogenean Gyrodactylus salaris Malmberg, 1957. J. Fish Biol. 37, 577-587.

Bakke, T. a, Harris, P.D., Hansen, H., Cable, J., Hansen, L.P., 2004. Susceptibility of Baltic and East Atlantic salmon Salmo salar stocks to Gyrodactylus salaris (Monogenea). Dis. Aquat. Organ. 58, 171-7. doi:10.3354/dao058171

Bansal, P.S., Smout, M.J., Wilson, D., Cobos Caceres, C., Dastpeyman, M., Sotillo, J., Seifert, J., Brindley, P.J., Loukas, A., Daly, N.L., 2017. Development of a Potent Wound Healing Agent Based on the Liver Fluke Granulin Structural Fold. J. Med. Chem. 60, 4258-4266. doi:10.1021/acs.jmedchem.7b00047

Barson, N.J., Aykanat, T., Hindar, K., Baranski, M., Bolstad, G.H., Fiske, P., Jacq, C., Jensen, A.J., Johnston, S.E., Karlsson, S., Kent, M., Moen, T., Niemelä, E., Nome, T., Næsje, T.F., Orell, P., Romakkaniemi, A., Sægrov, H., Urdal, K., Erkinaro, J., Lien, S., Primmer, C.R., 2015. Sex-dependent dominance at a single locus maintains variation in age at maturity in salmon. Nature 528, 405-408. doi:10.1038/nature16062

Bierne, N., Welch, J., Loire, E., Bonhomme, F., David, P., 2011. The coupling hypothesis: why genome scans may fail to map local adaptation genes. Mol. Ecol. 20, 2044-2072. doi:10.1111/j.1365-294X.2011.05080.x

Björck, S., 1995. A Review of the history of the Baltic Sea, 13.0-8.0 ka BP. Quat. Iternational 
27, 19-40.

Blank, U., Launay, P., Benhamou, M., Monteiro, R.C., 2009. Inhibitory ITAMs as novel regulators of immunity. Immunol. Rev. 232, 59-71. doi:10.1111/j.1600065X.2009.00832.x

Boehm, T., Hess, I., Swann, J.B., 2012. Evolution of lymphoid tissues. Trends Immunol. 33, 315-321. doi:10.1016/j.it.2012.02.005

Boilard, E., Lai, Y., Larabee, K., Balestrieri, B., Ghomashchi, F., Fujioka, D., Gobezie, R., Coblyn, J.S., Weinblatt, M.E., Massarotti, E.M., Thornhill, T.S., Divangahi, M., Remold, H., Lambeau, G., Gelb, M.H., Arm, J.P., Lee, D.M., 2010. A novel antiinflammatory role for secretory phospholipase A2 in immune complex-mediated arthritis. EMBO Mol. Med. 2, 172-187. doi:10.1002/emmm.201000072

Bourret, V., Kent, M.P., Primmer, C.R., Vasemägi, A., Karlsson, S., Hindar, K., McGinnity, P., Verspoor, E., Bernatchez, L., Lien, S., 2013. SNP-array reveals genome-wide patterns of geographical and potential adaptive divergence across the natural range of Atlantic salmon (Salmo salar). Mol. Ecol. 22, 532-551. doi:10.1111/mec.12003

Bowden, T.J., 2008. Modulation of the immune system of fish by their environment. Fish Shellfish Immunol. 25, 373-383. doi:10.1016/j.fsi.2008.03.017

Brohede, J., Dunne, R., McKay, J.D., Hannan, G.N., 2005. PPC: An algorithm for accurate estimation of SNP allele frequencies in small equimolar pools of DNA using data from high density microarrays. Nucleic Acids Res. 33, 1-7. doi:10.1093/nar/gni142

Brown, Ja.H., Gillooly, J.F., Allen, A.P., Savage, V.M., West, G.B., 2004. Toward a metabolic theory of ecology. Ecology 85, 1771-1789.

Calder, P.C., 2001. Polyunsaturated fatty acids, inflammation, and immunity. Lipids 36, 1007-1024.

Caraux, A., Kim, N., Bell, S.E., Zompi, S., Ranson, T., Lesjean-Pottier, S., Garcia-Ojeda, M.E., Turner, M., Colucci, F., 2017. Phospholipase C- y2 is essential for NK cell cytotoxicity and innate immunity to malignant and virally infected cells. Blood 107, 994-1003. doi:10.1182/blood-2005-06-2428.Supported

Carballeira, N.M., 2008. New advances in fatty acids as antimalarial, antimycobacterial and antifungal agents. Prog. Lipid Res. 47, 50-61. doi:10.1016/j.plipres.2007.10.002

Carval, D., Ferriere, R., 2010. A unified model for the coevolution of resistance, tolerance, and virulence. Evolution (N. Y). 64, 2988-3009. doi:10.1111/j.1558-5646.2010.01035.x

Castro, V., Grisdale-Helland, B., Jørgensen, S.M., Helgerud, J., Claireaux, G., Farrell, A.P., Krasnov, A., Helland, S.J., Takle, H., 2013. Disease resistance is related to inherent swimming performance in Atlantic salmon. BMC Physiol. 13, 1-12. doi:10.1186/14726793-13-1

Cepeda, V., Cofre, C., González, R., Mackenzie, S., Vidal, R., 2011. Identification of genes involved in immune response of Atlantic salmon (Salmo salar) to IPN virus infection, using expressed sequence tag (EST) analysis. Aquaculture 318, 54-60. doi:10.1016/j.aquaculture.2011.04.045

Chi, H., Bøgwald, J., Dalmo, R.A., Zhang, W., Hu, Y. hua, 2016. Th17 master transcription factors ROR $\alpha$ and ROR $\gamma$ regulate the expression of IL-17C, IL-17D and IL-17F in Cynoglossus semilaevis. Dev. Comp. Immunol. 55, 169-178. doi:10.1016/j.dci.2015.11.001

Chuang, E., Fisher, T.S., Morgan, R.W., Robbins, M.D., Duerr, J.M., Vander Heiden, M.G., Gardner, J.P., Hambor, J.E., Neveu, M.J., Thompson, C.B., 2000. The CD28 and CTLA4 Receptors Associate with the Serine/Threonine Phosphatase PP2A. Immunity 13, $313-$ 322. doi:10.1016/S1074-7613(00)00031-5

Conesa, A., Götz, S., García-Gómez, J.M., Terol, J., Talón, M., Robles, M., 2005. Blast2GO: a universal tool for annotation, visualization and analysis in functional genomics research. Bioinforma. Appl. Note 21, 3674-3676. doi:10.1093/bioinformatics/bti610 
Costa, M.M., Saraceni, P.R., Forn-Cuní, G., Dios, S., Romero, A., Figueras, A., Novoa, B., 2013. IL-22 is a key player in the regulation of inflammation in fish and involves innate immune cells and PI3K signaling. Dev. Comp. Immunol. 41, 746-755. doi:10.1016/j.dci.2013.08.021

Creelman, E.K., Hauser, L., Simmons, R.K., Templin, W.D., Seeb, L.W., 2011. Temporal and Geographic Genetic Divergence: Characterizing Sockeye Salmon Populations in the Chignik Watershed, Alaska, Using Single-Nucleotide Polymorphisms. Trans. Am. Fish. Soc. 140, 749-762. doi:10.1080/00028487.2011.584494

Dionne, M., Miller, K.M., Dodson, J.J., Bernatchez, L., 2009. MHC standing genetic variation and pathogen resistance in wild Atlantic salmon. Philos. Trans. R. Soc. B Biol. Sci. 364, 1555-1565. doi:10.1098/rstb.2009.0011

Dionne, M., Miller, K.M., Dodson, J.J., Caron, F., Bernatchez, L., 2007. Clinal variation in MHC diversity with temperature: evidence for the role of host-pathogen interaction on local adaptation in Atlantic salmon. Evolution 61, 2154-64. doi:10.1111/j.15585646.2007.00178.x

Elphinstone, M.S., Hinten, G.N., Anderson, M.J., Nock, C.J., 2003. An inexpensive and highthroughput procedure to extract and purify total genomic DNA for population studies. Mol. Ecol. Notes 3, 317-320. doi:10.1046/j.1471-8286.2003.00397.x

Faure, M., Lafont, F., 2013. Pathogen-induced autophagy signaling in innate immunity. J. Innate Immun. 5, 456-470. doi:10.1159/000350918

Flatman, P.W., 2002. Regulation of Na-K-2Cl cotransport by phosphorylation and proteinprotein interactions. Biochim. Biophys. Acta 1566, 140-151. doi:10.1016/S00052736(02)00586-2

Foll, M., Gaggiotti, O., 2008. A genome-scan method to identify selected loci appropriate for both dominant and codominant markers: a Bayesian perspective. Genetics 180, 977993. doi:10.1534/genetics.108.092221

Freeman, S.A., Grinstein, S., 2014. Phagocytosis: receptors, signal integration, and the cytoskeleton. Immunol. Rev. 262, 193-215.

Fumagalli, M., Sironi, M., Pozzoli, U., Ferrer-Admettla, A., Pattini, L., Nielsen, R., 2011. Signatures of Environmental Genetic Adaptation Pinpoint Pathogens as the Main Selective Pressure through Human Evolution. PLoS Genet. 7, 1-14. doi:10.1371/journal.pgen.1002355

Funder, S., Demidov, I., Yelovicheva, Y., 2002. Hydrography and mollusc faunas of the Baltic and the White Sea-North Sea seaway in the Eemian. Palaeogeogr. Palaeoclimatol. Palaeoecol. 184, 275-304.

Gilbey, J., Verspoor, E., Mo, T.A., Sterud, E., Olstad, K., Hytterød, S., Jones, C., Noble, L., 2006. Identification of genetic markers associated with Gyrodactylus salaris resistance in Atlantic salmon Salmo salar. Dis. Aquat. Organ. 71, 119-129. doi:10.3354/dao071119

Gillooly, J.F., Brown, J.H., West, G.B., Savage, V.M., Charnov, E.L., 2001. Effects of Size and Temperature on Metabolic Rate. Science (80-. ). 293, 2248-2251.

Goetzl, E.J., Wang, W., McGiffert, C., Huang, M.C., Gräler, M.H., 2004. Sphingosine 1phosphate and its $\mathrm{G}$ protein-coupled receptors constitute a multifunctional immunoregulatory system. J. Cell. Biochem. 92, 1104-1114. doi:10.1002/jcb.20053

Günther, T., Coop, G., 2013. Robust identification of local adaptation from allele frequencies. Genetics 195, 205-220. doi:10.1534/genetics.113.152462

Guo, B., Li, Z., Merilä, J., 2016. Population genomic evidence for adaptive differentiation in the Baltic Sea herring. Mol. Ecol. 25, 2833-2852. doi:10.1111/mec.13657

Haarder, S., Kania, P.W., Bahlool, Q.Z.M., Buchmann, K., 2013. Expression of immune relevant genes in rainbow trout following exposure to live Anisakis simplex larvae. Exp. Parasitol. 135, 564-569. doi:10.1016/j.exppara.2013.09.011 
811

812

813

814

815

816

817

818

819

820

821

822

823

824

825

826

827

828

829

830

831

832

833

834

835

836

837

838

839

840

841

842

843

Haasl, R.J., Payseur, B.A., 2016. Fifteen years of genomewide scans for selection: trends , lessons and unaddressed genetic sources of complication. Mol. Ecol. 25, 5-23. doi:10.1111/mec.13339

Hanington, P.C., Tam, J., Katzenback, B.A., Hitchen, S.J., Barreda, D.R., Belosevic, M., 2009. Development of macrophages of cyprinid fish. Dev. Comp. Immunol. 33, 411429. doi:10.1016/j.dci.2008.11.004

Harbige, L.S., 2003. Fatty acids, the immune response, and autoimmunity: a question of n-6 essentiality and the balance between n-6 and n-3. Lipids 38, 323-341.

Hedrick, M.S., Hillman, S.S., Drewes, R.C., Withers, P.C., 2013. Lymphatic regulation in nonmammalian vertebrates. J. Appl. Physiol. 115, 297-308. doi:10.1152/japplphysiol.00201.2013

Heinz, L.X., Baumann, C.L., Köberlin, M.S., Snijder, B., Gawish, R., Shui, G., Sharif, O., Aspalter, I.M., Müller, A.C., Kandasamy, R.K., Breitwieser, F.P., Pichlmair, A., Bruckner, M., Rebsamen, M., Blüml, S., Karonitsch, T., Fauster, A., Colinge, J., Bennett, K.L., Knapp, S., Wenk, M.R., Superti-Furga, G., 2015. The Lipid-Modifying Enzyme SMPDL3B Negatively Regulates Innate Immunity. Cell Rep. 11, 1919-1928. doi:10.1016/j.celrep.2015.05.006

Hiroi, J., Yasumasu, S., Mccormick, S.D., Hwang, P.-P., Kaneko, T., 2008. Evidence for an apical $\mathrm{Na}-\mathrm{Cl}$ cotransporter involved in ion uptake in a teleost fish. J. Exp. Biol. 211, 2584-2599. doi:10.1242/jeb.018663

Hoban, S., Kelley, J.L., Lotterhos, K.E., Antolin, M.F., Bradburd, G., Lowry, D.B., Poss, M.L., Reed, L.K., Storfer, A., Whitlock, M.C., 2016. Finding the Genomic Basis of Local Adaptation: Pitfalls, Practical Solutions, and Future Directions. Am. Nat. 188, 379-397. doi:10.1086/688018

Hoffmann, E.K., Hoffmann, E., Lang, F., Zadunaisky, J.A., 2002. Control of Cl- transport in the operculum epithelium of Fundulus heteroclitus: long- and short-term salinity adaptation. Biochim. Biophys. Acta 1566, 129-139.

Holm, H.J., Skugor, S., Bjelland, A.K., Radunovic, S., Wadsworth, S., Koppang, E.O., Evensen, Ø., 2017. Contrasting expression of immune genes in scaled and scaleless skin of Atlantic salmon infected with young stages of Lepeophtheirus salmonis. Dev. Comp. Immunol. 67, 153-165. doi:10.1016/j.dci.2016.10.008

Jensen, L.F., Hansen, M.M., Carlsson, J., Loeschcke, V., Mensberg, K.L.D., 2005. Spatial and temporal genetic differentiation and effective population size of brown trout (Salmo trutta, L.) in small Danish rivers. Conserv. Genet. 6, 615-621. doi:10.1007/s10592-0059014-8

Johnsen, B.O., Jensen, A.J., 1991. The Gyrodactylus story in Norway. Aquaculture 98, 289302.

Kadiri, S., Monnier, C., Ganbold, M., Ledent, T., Capeau, J., Antoine, B., 2015. The nuclear retinoid-related orphan receptor-alpha regulates adipose tissue glyceroneogenesis in addition to hepatic gluconeogenesis. Am. J. Physiol. Endocrinol. Metab. 309, 105-114. doi:10.1152/ajpendo.00518.2014

Kaltz, O., Shykoff, J. a, 1998. Local adaptation in host-parasite systems. Heredity (Edinb). 81, 361-370. doi:10.1046/j.1365-2540.1998.00435.x

Kang, C., Tsai, H., Liu, C., Lee, T., Hwang, P.-P., 2010. Salinity-dependent expression of a $\mathrm{Na}+, \mathrm{K}+, 2 \mathrm{Cl}-$ cotransporter in gills of the brackish medaka Oryzias dancena: A molecular correlate for hyposmoregulatory endurance. Comp. Biochem. Physiol. Part A 157, 7-18. doi:10.1016/j.cbpa.2010.05.013

Kania, P.W., Evensen, O., Larsen, T.B., Buchmann, K., 2010. Molecular and immunohistochemical studies on epidermal responses in Atlantic salmon Salmo salar L. induced by Gyrodactylus salaris Malmberg, 1957. J. Helminthol. 84, 166-172. doi:10.1017/S0022149X09990460 
Kiiskinen, P., Huuskonen, H., Hyvärinen, H., Piironen, J., 2003. Effects of daylength and winter fasting on growth and smolting of one-year-old Saimaa landlocked salmon (Salmo salar m. sebago Girard) under fish farm conditions. Ann. Zool. Fennici 40, 441458.

Kjærner-Semb, E., Ayllon, F., Furmanek, T., Wennevik, V., Dahle, G., Niemelä, E., Ozerov, M., Vähä, J.-P., Glover, K.A., Rubin, C.J., Wargelius, A., Edvardsen, R.B., 2016. Atlantic salmon populations reveal adaptive divergence of immune related genes - a duplicated genome under selection. BMC Genomics 17, 1-12. doi:10.1186/s12864-0162867-z

Krasnov, A., Skugor, S., Todorcevic, M., Glover, K.A., Nilsen, F., 2012. Gene expression in Atlantic salmon skin in response to infection with the parasitic copepod Lepeophtheirus salmonis, cortisol implant, and their combination. BMC Genomics 13, 1-15. doi:10.1186/1471-2164-13-130

Krasnov, A., Timmerhaus, G., Schiøtz, B.L., Torgersen, J., Afanasyev, S., Iliev, D., Jørgensen, J., Takle, H., Jørgensen, S.M., 2011. Genomic survey of early responses to viruses in Atlantic salmon, Salmo salar L. Mol. Immunol. 49, 163-174. doi:10.1016/j.molimm.2011.08.007

Kudersky, L., Ieshko, E., Schulman, B., 2003. Distribution and range formation history of the monogenean Gyrodactylus salaris Malmberg, 1957 - a parasite of juvenile Atlantic salmon Salmo salar Linnaeus, in: Atlantic Salmon Biology, Conservation and Restoration. pp. 77-83.

Kumari, J., Larsen, A.N., Bogwald, J., Dalmo, R.A., 2009. Interleukin-17D in Atlantic salmon (Salmo salar): molecular characterization, 3D modelling and promoter analysis. Fish Shellfish Immunol. 27, 647-659. doi:10.1016/j.fsi.2009.08.009

Kusakabe, M., Ishikawa, A., Ravinet, M., Yoshida, K., Makino, T., Toyoda, A., Fujiyama, A., Kitano, J., 2017. Genetic basis for variation in salinity tolerance between stickleback ecotypes. Mol. Ecol. 26, 304-319. doi:10.1111/mec.13875

Kuusela, J., Holopainen, R., Meinilä, M., Anttila, P., Koski, P., Ziętara, M.S., Veselov, A., Primmer, C.R., Lumme, J., 2009. Clonal structure of salmon parasite Gyrodactylus salaris on a coevolutionary gradient on Fennoscandian salmon (Salmo salar). Ann. Zool. Fennici 46, 21-33.

Kuusela, J., Zietara, M.S., Lumme, J., 2007. Hybrid origin of Baltic salmon-specific parasite Gyrodactylus salaris: a model for speciation by host switch for hemiclonal organisms. Mol. Ecol. 16, 5234-45. doi:10.1111/j.1365-294X.2007.03562.x

Li, G., Zhao, Y., Wang, J., Liu, B., Sun, X., Guo, S., Feng, J., 2017. Transcriptome profiling of developing spleen tissue and discovery of immune-related genes in grass carp (Ctenopharyngodon idella). Fish Shellfish Immunol. 60, 400-410. doi:10.1016/j.fsi.2016.12.012

Li, J., Li, Y., Cao, Y., Yuan, M., Gao, Z., Guo, X., Zhu, F., Wang, Y., Xu, J., 2014. Polycomb chromobox (Cbx) 7 modulates activation-induced CD4+ T cell apoptosis. Arch. Biochem. Biophys. 564, 184-188. doi:10.1016/j.abb.2014.10.004

Lien, S., Koop, B.F., Sandve, S.R., Miller, J.R., Kent, M.P., Nome, T., Hvidsten, T.R., Leong, J.S., Minkley, D.R., Zimin, A., Grammes, F., Grove, H., Gjuvsland, A., Walenz, B., Hermansen, R.A., von Schalburg, K., Rondeau, E.B., Di Genova, A., Samy, J.K.A., Olav Vik, J., Vigeland, M.D., Caler, L., Grimholt, U., Jentoft, S., Inge Våge, D., de Jong, P., Moen, T., Baranski, M., Palti, Y., Smith, D.R., Yorke, J.A., Nederbragt, A.J., Tooming-Klunderud, A., Jakobsen, K.S., Jiang, X., Fan, D., Hu, Y., Liberles, D.A., Vidal, R., Iturra, P., Jones, S.J.M., Jonassen, I., Maass, A., Omholt, S.W., Davidson, W.S., 2016. The Atlantic salmon genome provides insights into rediploidization. Nature 533, 200-205. doi:10.1038/nature 17164

Lillico, D.M.E., Zwozdesky, M.A., Pemberton, J.G., Deutscher, J.M., Jones, L.O., Chang, 
J.P., Stafford, J.L., 2017. Teleost leukocyte immune-type receptors activate distinct phagocytic modes for target acquisition and engulfment. J. Leukoc. Biol. 98, 235-248. doi:10.1189/jlb.2A0215-039RR

Lim, J., Wiedemann, A., Tzircotis, G., Monkley, S.J., Critchley, D.R., Caron, E., 2007. An Essential Role for Talin during aMB2-mediated Phagocytosis. Mol. Biol. Cell 18, 976985. doi:10.1091/mbc.E06

Limborg, M.T., Blankenship, S.M., Young, S.F., Utter, F.M., Seeb, L.W., Hansen, M.H.H., Seeb, J.E., 2012a. Signatures of natural selection among lineages and habitats in Oncorhynchus mykiss. Ecol. Evol. 2, 1-18. doi:10.1002/ece3.59

Limborg, M.T., Helyar, S.J., De Bruyn, M., Taylor, M.I., Nielsen, E.E., Ogden, R., Carvalho, G.R., Bekkevold, D., 2012b. Environmental selection on transcriptome-derived SNPs in a high gene flow marine fish, the Atlantic herring (Clupea harengus). Mol. Ecol. 21, 3686-703. doi:10.1111/j.1365-294X.2012.05639.x

Lindenstrom, T., Sigh, J., Dalgaard, M.B., Buchmann, K., 2006. Skin expression of IL-1b in East Atlantic salmon, Salmo salar L., highly susceptible to Gyrodactylus salaris infection is enhanced compared to a low susceptibility Baltic stock. J. Fish Dis. 29, 123128.

Lionetto, M.G., Schettino, T., 2006. The Na+ K+2Cl- cotransporter and the osmotic stress response in a model salt transport epithelium. Acta Physiol. 187, 115-124. doi:10.1111/j.1748-1716.2006.01536.x

Lumme, J., Ozerov, M.Y., Veselov, A.E., Primmer, C.R., 2016. The Formation of Landlocked Populations of Atlantic Salmon, in: Evolutionary Biology of the Atlantic Salmon. pp. 26-43.

Mace, E.M., Monkley, S.J., Critchley, D.R., Takei, F., 2009. A Dual Role for Talin in NK Cell Cytotoxicity: Activation of LFA-1-Mediated Cell Adhesion and Polarization of NK Cells. J. Immunol. 182, 948-956. doi:10.4049/jimmunol.182.2.948

Makrinos, D.L., Bowden, T.J., 2016. Natural environmental impacts on teleost immune function. Fish Shellfish Immunol. 53, 50-57. doi:10.1016/j.fsi.2016.03.008

Matejusová, I., Felix, B., Sorsa-Leslie, T., Gilbey, J., Noble, L.R., Jones, C.S., Cunningham, C.O., 2006. Gene expression profiles of some immune relevant genes from skin of susceptible and responding Atlantic salmon (Salmo salar L.) infected with Gyrodactylus salaris (Monogenea) revealed by suppressive subtractive hybridisation. Int. J. Parasitol. 36, 1175-1183. doi:10.1016/j.ijpara.2006.04.009

Medzhitov, R., 2007. Recognition of microorganisms and activation of the immune response. Nature 449, 819-826. doi:10.1038/nature06246

Mikrou, A., Marioli, D., Papanastasiou, A.D., Zarkadis, I.K., 2009. CR3 complement receptor: Cloning and characterization in rainbow trout. Fish Shellfish Immunol. 26, 1928. doi:10.1016/j.fsi.2008.10.005

Mitchell, P.S., Emerman, M., Malik, H.S., 2013. An evolutionary perspective on the broad antiviral specificity of MxA. Curr. Opin. Microbiol. 16, 493-499. doi:10.1016/j.mib.2013.04.005

Moen, T., Baranski, M., Sonesson, A.K., Kjøglum, S., 2009. Confirmation and fine-mapping of a major QTL for resistance to infectious pancreatic necrosis in Atlantic salmon (Salmo salar): population-level associations between markers and trait. BMC Genomics 10, 1-14. doi:10.1186/1471-2164-10-368

Moen, T., Torgersen, J., Santi, N., Davidson, W.S., Baranski, M., Ødegård, J., Kjøglum, S., Velle, B., Kent, M., Lubieniecki, K.P., Isdal, E., Lien, S., 2015. Epithelial Cadherin Determines Resistance to Infectious Pancreatic Necrosis Virus in Atlantic Salmon. Genetics 200, 1313-1326. doi:10.1534/genetics.115.175406

Nakamura, T., Liu, Y., Hiratal, D., Nambal, H., Harada, S., Hirokawa, T., Miyakawa, T., 1993. Protein phosphatase type 2B (calcineurin)-mediated, FK506-sensitive regulation 
of intracellular ions in yeast is an important determinant for adaptation to high salt stress conditions. EMBO J. 12, 4063-4071.

Nakanishi, T., Shibasaki, Y., Matsuura, Y., 2015. T Cells in Fish. Biology (Basel). 4, 640663. doi:10.3390/biology4040640

Narum, S.R., Zendt, J.S., Frederiksen, C., Campbell, N., Matala, A., Sharp, W.R., 2011. Candidate genetic markers associated with anadromy in Oncorhynchus mykiss of the Klickitat River. Trans. Am. Fish. Soc. 140, 843-854. doi:10.1080/00028487.2011.588131

Naumenko, M.A., Karetnikov, S.G., Tikhomirov, A.I., 1996. Main features of the thermal regime of Lake Ladoga during the ice-free period. Hydrobiologia 322.

Nielsen, E.E., Hemmer-Hansen, J., Poulsen, N.A., Loeschcke, V., Moen, T., Johansen, T., Mittelholzer, C., Taranger, G., Ogden, R., Carvalho, G.R., 2009. Genomic signatures of local directional selection in a high gene flow marine organism; the Atlantic cod (Gadus morhua). BMC Evol. Biol. 9, 1-11. doi:10.1186/1471-2148-9-276

Nielsen, R., Williamson, S., Kim, Y., Hubisz, M.J., Clark, A.G., Bustamante, C., 2005. Genomic scans for selective sweeps using SNP data. Genome Res. 15, 1566-75. doi: $10.1101 /$ gr.4252305

Nilsen, T.O., Ebbesson, L.O.E., Kiilerich, P., Björnsson, B.T., Madsen, S.S., McCormick, S.D., Stefansson, S.O., 2008. Endocrine systems in juvenile anadromous and landlocked Atlantic salmon (Salmo salar): seasonal development and seawater acclimation. Gen. Comp. Endocrinol. 155, 762-72. doi:10.1016/j.ygcen.2007.08.006

Nilsen, T.O., Ebbesson, L.O.E., Stefansson, S.O., 2003. Smolting in anadromous and landlocked strains of Atlantic salmon (Salmo salar). Aquaculture 222, 71-82. doi:10.1016/S0044-8486(03)00103-0

Nilsson, J., Gross, R., Asplund, T., Dove, O., Jansson, H., Kelloniemi, J., Kohlmann, K., Löytynoja, A., Nielsen, E.E., Paaver, T., Primmer, C.R., Titov, S., Vasemägi, A., Veselov, A., Ost, T., Lumme, J., 2001. Matrilinear phylogeography of Atlantic salmon (Salmo salar L.) in Europe and postglacial colonization of the Baltic Sea area. Mol. Ecol. 10, 89-102.

Oleksyk, T.K., Smith, M.W., O’Brien, S.J., 2010. Genome-wide scans for footprints of natural selection. Philos. Trans. R. Soc. B Biol. Sci. 365, 185-205. doi:10.1098/rstb.2009.0219

Oleksyk, T.K., Zhao, K., De La Vega, F.M., Gilbert, D.A., O’Brien, S.J., Smith, M.W., 2008. Identifying selected regions from heterozygosity and divergence using a light-coverage genomic dataset from two human populations. PLoS One 3, 1-15. doi:10.1371/journal.pone.0001712

Orr, H.A., 2000. Adaptation and the cost of complexity. Evolution (N. Y). 54, 13-20.

Oshiumi, H., Sakai, K., Matsumoto, M., Seya, T., 2010. DEAD/H BOX 3 (DDX3) helicase binds the RIG-I adaptor IPS-1 to up-regulate IFN-B-inducing potential. Eur. J. Immunol. 40, 940-948. doi:10.1002/eji.200940203

Ozerov, M., Veselov, A.E., Lumme, J., Primmer, C.R., 2013. Temporal variation of genetic composition in Atlantic salmon populations from the Western White Sea Basin: influence of anthropogenic factors? BMC Genet. 14, 1-15. doi:10.1186/1471-2156-1488

Ozerov, M.Y., Veselov, A.E., Lumme, J., Primmer, C.R., 2012. "Riverscape" genetics: river characteristics influence the genetic structure and diversity of anadromous and freshwater Atlantic salmon (Salmo salar) populations in northwest Russia. Can. J. Fish. Aquat. Sci. 69, 1-12. doi:10.1139/f2012-114

Ozerov, M.Y., Veselov, A.J., Lumme, J., Primmer, C.R., 2010. Genetic structure of freshwater Atlantic salmon (Salmo salar L.) populations from the lakes Onega and Ladoga of northwest Russia and implications for conservation. Conserv. Genet. 11, 
1711-1724. doi:10.1007/s10592-010-0064-1

Palstra, F.P., Ruzzante, D.E., 2010. A temporal perspective on population structure and gene flow in Atlantic salmon (Salmo salar) in Newfoundland, Canada. Can. J. Fish. Aquat. Sci. 67, 225-242. doi:10.1139/F09-176

Pankratz, V.S., Vierkant, R.A., Byrne, M.M.O., Ovsyannikova, I.G., Poland, G.A., 2010. Associations between SNPs in candidate immune-relevant genes and rubella antibody levels: a multigenic assessment. BMC Immunol. 11, 1-10.

Papakostas, S., Vøllestad, L.A., Bruneaux, M., Aykanat, T., Vanoverbeke, J., Ning, M., Primmer, C.R., Leder, E.H., 2014. Gene pleiotropy constrains gene expression changes in fish adapted to different thermal conditions. Nat. Commun. 5, 1-9. doi:10.1038/ncomms5071

Park, B., Buti, L., Lee, S., Matsuwaki, T., Spooner, E., Brinkmann, M.M., Nishihara, M., Ploegh, H.L., 2011. Granulin Is a Soluble Cofactor for Toll-like Receptor 9 Signaling. Immunity 34, 505-513. doi:10.1016/j.immuni.2011.01.018

Peng, J., Larondelle, Y., Pham, D., Ackman, R.G., Rollin, X., 2003. Polyunsaturated fatty acid profiles of whole body phospholipids and triacylglycerols in anadromous and landlocked Atlantic salmon (Salmo salar L .) fry. Comp. Biochem. Physiol. 134, 335348. doi:10.1016/S1096-4959(02)00263-4

Pritchard, V.L., Erkinaro, J., Kent, M.P., Niemelä, E., Orell, P., Lien, S., Primmer, C.R., 2016. Single nucleotide polymorphisms to discriminate different classes of hybrid between wild Atlantic salmon and aquaculture escapees. Evol. Appl. 9, 1017-1031. doi:10.1111/eva.12407

Przeworski, M., Coop, G., Wall, J.D., 2005. The signature of positive selectionon standing genetic variation. Evolution (N. Y). 59, 2312-2323.

Purcell, S., Neale, B., Todd-Brown, K., Thomas, L., Ferreira, M.A.R., Bender, D., Maller, J., Sklar, P., de Bakker, P.I.W., Daly, M.J., Sham, P.C., 2007. PLINK: a tool set for wholegenome association and population-based linkage analyses. Am. J. Hum. Genet. 81, 559-575. doi:10.1086/519795

Quinlan, A.R., Hall, I.M., 2010. BEDTools: a flexible suite of utilities for comparing genomic features. Bioinformatics 26, 841-842. doi:10.1093/bioinformatics/btq033

Råberg, L., Sim, D., Read, A.F., 2007. Disentangling genetic variation for resistance and tolerance to infectious diseases in animals. Science (80-. ). 318, 812-814. doi: $10.1126 /$ science. 1148526

$\mathrm{R}$ Core Team, 2016. A language and environment for statistical computing. R Foundation for Statistical Computing, Vienna, Austria. https://www.r-project.org/.

Rebl, A., Goldammer, T., Seyfert, H.-M., 2010. Toll-like receptor signaling in bony fish. Vet. Immunol. Immunopathol. 134, 139-150. doi:10.1016/j.vetimm.2009.09.021

Reyes-Lopez, F.E., Romeo, J.S., Vallejos-Vidal, E., Reyes-Cerpa, S., Sandino, A.M., Tort, L., Mackenzie, S., Imarai, M., 2015. Differential immune gene expression profiles in susceptible and resistant full-sibling families of Atlantic salmon (Salmo salar) challenged with infectious pancreatic necrosis virus (IPNV ). Dev. Comp. Immunol. 53, 210-221. doi:10.1016/j.dci.2015.06.017

Saarnisto, M., Saarinen, T., 2001. Deglaciation chronology of the Scandinavian Ice Sheet from the Lake Onega Basin to the Salpausselkä End Moraines. Glob. Planet. Change 31, 387-405.

Sadeghi, H., Gupta, Y., Möller, S., Samavedam, U.K., Behnen, M., Kasprick, A., Bieber, K., Müller, S., Kalies, K., de Castro Marques, A., Recke, A., Schmidt, E., Zillikens, D., Laskay, T., Mariani, J., Ibrahim, S.M., Ludwig, R.J., 2015. The retinoid-related orphan receptor alpha is essential for the end-stage effector phase of experimental epidermolysis bullosa acquisita. J. Pathol. 237, 111-122. doi:10.1002/path.4556

Sancho, D., Vicente-Manzanares, M., Mittelbrunn, M., Montoya, M.C., Gordon-Alonso, M., 
Serrador, J.M., Sanchez-Madrid, F., 2002. Regulation of microtubule- organizing center orientation and actomyosin cytoskeleton rearrangement during immune interactions. Immunol. Rev. 189, 84-97.

Schiöth, H.B., Fredriksson, R., 2005. The GRAFS classification system of G-protein coupled receptors in comparative perspective. Gen. Comp. Endocrinol. 142, 94-101. doi:10.1016/j.ygcen.2004.12.018

Schlötterer, C., 2003. Hitchhiking mapping - functional genomics from the population genetics perspective. Trends Genet. 19, 32-38.

Schröder, M., 2011. Viruses and the human DEAD-box helicase DDX3: inhibition or exploitation? Biochem. Soc. Trans. 39, 679-683. doi:10.1042/BST0390679

Shiozaki, K., Russell, P., 1995. Counteractive roles of protein phosphatase 2C (PP2C) and a MAP kinase kinase homolog in the osmoregulation of fission yeast. EMBO J. 14, 492502.

Smit, M.J., Vischer, H.F., Bakker, R.A., Jongejan, A., Timmerman, H., Pardo, L., Leurs, R., 2007. Pharmacogenomic and structural analysis of constitutive $G$ protein-coupled receptor activity. Annu. Rev. Pharmacol. Toxicol. 47, 53-87. doi:10.1146/annurev.pharmtox.47.120505.105126

Smout, M.J., Laha, T., Mulvenna, J., Sripa, B., Suttiprapa, S., Jones, A., Brindley, P.J., Loukas, A., 2009. A granulin-like growth factor secreted by the carcinogenic liver fluke, Opisthorchis viverrini, promotes proliferation of host cells. PLoS Pathog. 5, 1-16. doi:10.1371/journal.ppat.1000611

Sommer, S., 2005. The importance of immune gene variability (MHC) in evolutionary ecology and conservation. Front. Zool. 2, 1-18. doi:10.1186/1742-9994-2-16

Stanton, R.J., Prod'homme, V., Purbhoo, M.A., Moore, M., Aicheler, R.J., Heinzmann, M., Bailer, S.M., Haas, J., Antrobus, R., Weekes, M.P., Lehner, P.J., Vojtesek, B., Miners, K.L., Man, S., Wilkie, G.S., Davison, A.J., Wang, E.C.Y., Tomasec, P., Wilkinson, G.W.G., 2014. HCMV pUL135 Remodels the Actin Cytoskeleton to Impair Immune Recognition of Infected Cells. Cell Host Microbe 16, 201-214. doi:10.1016/j.chom.2014.07.005

Sun, Y., Liu, C., Paul, J., Evans, L.P., Tian, K.T., Zhang, B., Stahl, A., Pu, W.T., Kamenecka, T.M., Solt, L.A., Chen, J., 2015. Nuclear receptor ROR $\alpha$ regulates pathologic retinal angiogenesis by modulating SOCS3-dependent inflammation. PNAS 112, 10401-10406. doi: $10.1073 /$ pnas. 1504387112

Sunyer, J.O., 2013. Fishing for mammalian paradigms in the teleost immune system. Nat. Immunol. 14, 1-19. doi:10.1007/s11103-011-9767-z.Plastid

Tadiso, T.M., Krasnov, A., Skugor, S., Afanasyev, S., Hordvik, I., Nilsen, F., 2011. Gene expression analyses of immune responses in Atlantic salmon during early stages of infection by salmon louse (Lepeophtheirus salmonis) revealed bi-phasic responses coinciding with the copepod-chalimus transition. BMC Genomics 12, 1-17.

Tolstikov, A. V., Petrov, M.P., 2006. Mean multiannual temperature regime of the surface water layer in the near-shore regions of the White Sea. Oceanology 46, 318-324. doi: 10.1134/S0001437006030039

Tonteri, A., Titov, S., Veselov, A., Zubchenko, A., Koskinen, M.T., Lesbarrères, D., Kaluzchin, S., Bakhmet, I., Lumme, J., Primmer, C.R., 2005. Phylogeography of anadromous and non-anadromous Atlantic salmon (Salmo salar) from northern Europe. Ann. Zool. Fennici 41, 1-22.

Tonteri, A., Vasemägi, A., Lumme, J., Primmer, C.R., 2010. Beyond MHC: signals of elevated selection pressure on Atlantic salmon (Salmo salar) immune-relevant loci. Mol. Ecol. 19, 1273-1282. doi:10.1111/j.1365-294X.2010.04573.x

Tonteri, A., Vasemägi, A., Lumme, J., Primmer, C.R., 2008. Use of differential expression data for identification of novel immune relevant expressed sequence tag-linked 
microsatellite markers in Atlantic salmon (Salmo salar L.). Mol. Ecol. Resour. 8, 14861490. doi:10.1111/j.1755-0998.2008.02317.x

Tonteri, A., Veselov, A.J., Titov, S., Lumme, J., Primmer, C.R., 2007. The effect of migratory behaviour on genetic diversity and population divergence: a comparison of anadromous and freshwater Atlantic salmon Salmo salar. J. Fish Biol. 70, 381-398. doi:10.1111/j.1095-8649.2007.01519.x

Tonteri, A., Veselov, A.J., Zubchenko, A. V, Lumme, J., Primmer, C.R., 2009. Microsatellites reveal clear genetic boundaries among Atlantic salmon (Salmo salar) populations from the Barents and White seas, northwest Russia. Can. J. Fish. Aquat. Sci. 66, 717-735. doi:10.1139/F09-010

Trombetta, E.S., Ebersold, M., Garrett, M.P., Mellman, I., 2003. Activation of Lysosomal Function During Dendritic Cell Maturation. Science (80-. ). 299, 1400-1403. doi:10.1126/science. 1080106

Vähä, J.-P., Erkinaro, J., Niemelä, E., Primmer, C.R., 2008. Temporally stable genetic structure and low migration in an Atlantic salmon population complex: implications for conservation and management. Evol. Appl. 1, 137-154. doi:10.1111/j.17524571.2007.00007.x

Vasemägi, A., Nilsson, J., Primmer, C.R., 2005. Expressed sequence tag-linked microsatellites as a source of gene-associated polymorphisms for detecting signatures of divergent selection in atlantic salmon (Salmo salar L.). Mol. Biol. Evol. 22, 1067-76. doi: 10.1093/molbev/msi093

Vilas, R., Vandamme, S.G., Vera, M., Bouza, C., Maes, G.E., Volckaert, F.A.M., Martínez, P., 2015. A genome scan for candidate genes involved in the adaptation of turbot (Scophthalmus maximus). Mar. Genomics 23, 77-86. doi:10.1016/j.margen.2015.04.011 Wagner, G.P., Zhang, J., 2011. The pleiotropic structure of the genotype-phenotype map: the evolvability of complex organisms. Nat. Rev. Genet. 12, 204-213. doi:10.1038/nrg2949

Wang, T., Diaz-Rosales, P., Costa, M.M., Campbell, S., Snow, M., Collet, B., Martin, S.A.M., Secombes, C.J., 2011. Functional Characterization of a Nonmammalian IL-21: Rainbow Trout Oncorhynchus mykiss IL-21 Upregulates the Expression of the Th Cell Signature Cytokines IFN- $\gamma$, IL-10, and IL-22. J. Immunol. 186, 708-721. doi:10.4049/jimmunol.1001203

Watkins, G.R., Wang, N., Mazalouskas, M.D., Gomez, R.J., Guthrie, C.R., Kraemer, B.C., Schweiger, S., Spiller, B.W., Wadzinski, B.E., 2012. Monoubiquitination promotes calpain cleavage of the protein phosphatase $2 \mathrm{~A}$ (PP2A) regulatory subunit a4, altering PP2A stability and microtubule-associated protein phosphorylation. J. Biol. Chem. 287, 24207-24215. doi:10.1074/jbc.M112.368613

Whitlock, M.C., Lotterhos, K.E., 2015. Reliable Detection of Loci Responsible for Local Adaptation: Inference of a Null Model through Trimming the Distribution of Fst*. Am. Nat. 186, 26-36. doi:10.1086/682949

Winder, M., Schindler, D.E., 2004. Climate change uncouples trophic interactions in an Aquatic ecosystem. Ecology 85, 2100-2106.

Yamamoto, H., Hatano, M., Iitsuka, Y., Mahyar, N.-S., Yamamoto, M., Tokuhisa, T., 1995. Two forms of Hox11, a T cell leukemia oncogene, are expressed in fetal spleen but not in primary lymphocytes. Mol. Immunol. 32, 1177-1182. doi:10.1016/01615890(95)00100-X

Yang, X., Downes, M., Yu, R.T., Bookout, A.L., He, W., Straume, M., Mangelsdorf, D.J., Evans, R.M., 2006. Nuclear Receptor Expression Links the Circadian Clock to Metabolism. Cell 126, 801-810. doi:10.1016/j.cell.2006.06.050

Yang, X.O., Pappu, B.P., Nurieva, R., Akimzhanov, A., Kang, H.S., Chung, Y., Ma, L., Shah, B., Panopoulos, A.D., Schluns, K.S., Watowich, S.S., Tian, Q., Jetten, A.M., Dong, C., 2008. T Helper 17 Lineage Differentiation Is Programmed by Orphan Nuclear 
Receptors RORa and RORy. Immunity 28, 29-39. doi:10.1016/j.immuni.2007.11.016

Zapata, A., Diez, B., Cejalvo, T., Gutiérrez-De Frías, C., Cortés, A., 2006. Ontogeny of the immune system of fish. Fish Shellfish Immunol. 20, 126-136. doi:10.1016/j.fsi.2004.09.005

Zhu, L., Nie, L., Zhu, G., Xiang, L., Shao, J., 2013. Advances in research of fish immunerelevant genes: A comparative overview of innate and adaptive immunity in teleosts. Dev. Comp. Immunol. 39, 39-62. doi:10.1016/j.dci.2012.04.001

Zueva, K.J., Lumme, J., Veselov, A.E., Kent, M.P., Lien, S., Primmer, C.R., 2014. Footprints of Directional Selection in Wild Atlantic Salmon Populations: Evidence for ParasiteDriven Evolution? PLoS One 9, 1-16. doi:10.5061/dryad.gm367 


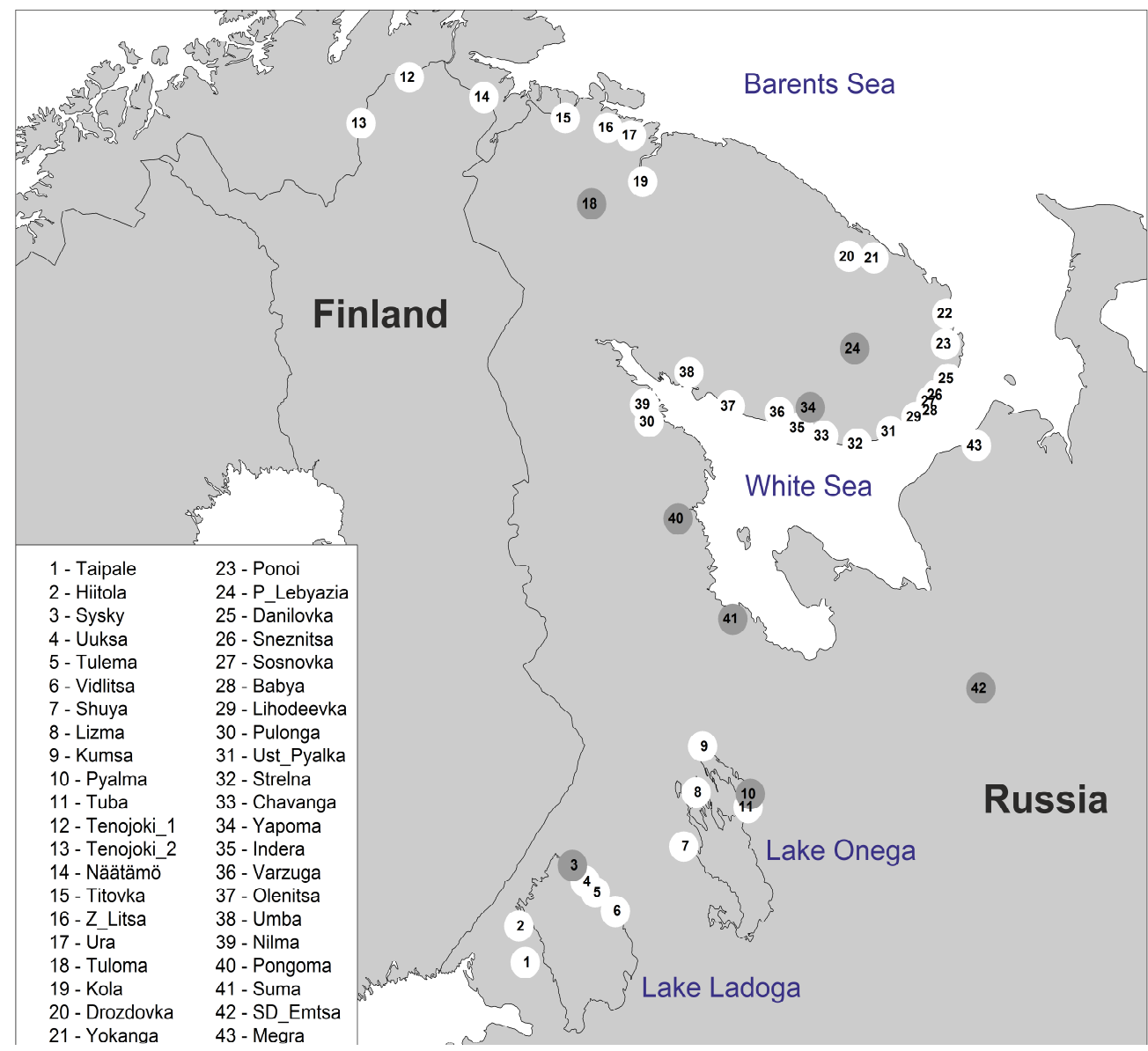

Figure 1. Sampling site locations. Populations that were also studied previously (Zueva et al. 2014) are presented in grey, while white circles indicate populations that were added for this study.

(Figure 1 is intended as a 2-column fitting image; colour) 


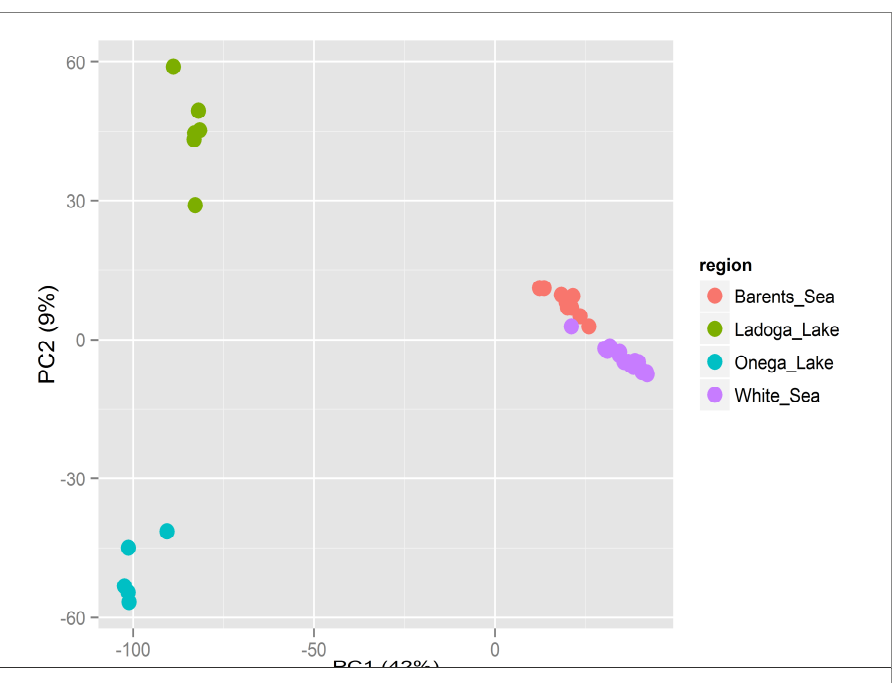

1208

Figure 2. Population sub-structuring based on principal component (PC) analysis. Individual populations plotted as dots and coloured based on their geographic location; percentage of variance explained by PC1 and PC2 is given in brackets.

(Figure 2 is intended as a 1 or 1.5 -column fitting image; colour) 


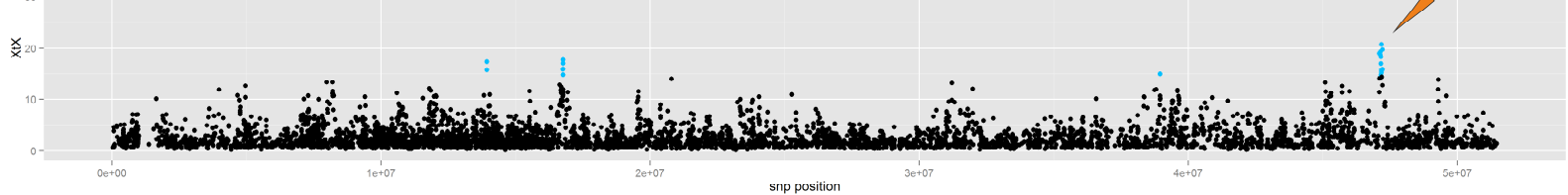

Barents \& White Seas vs. Onega lake

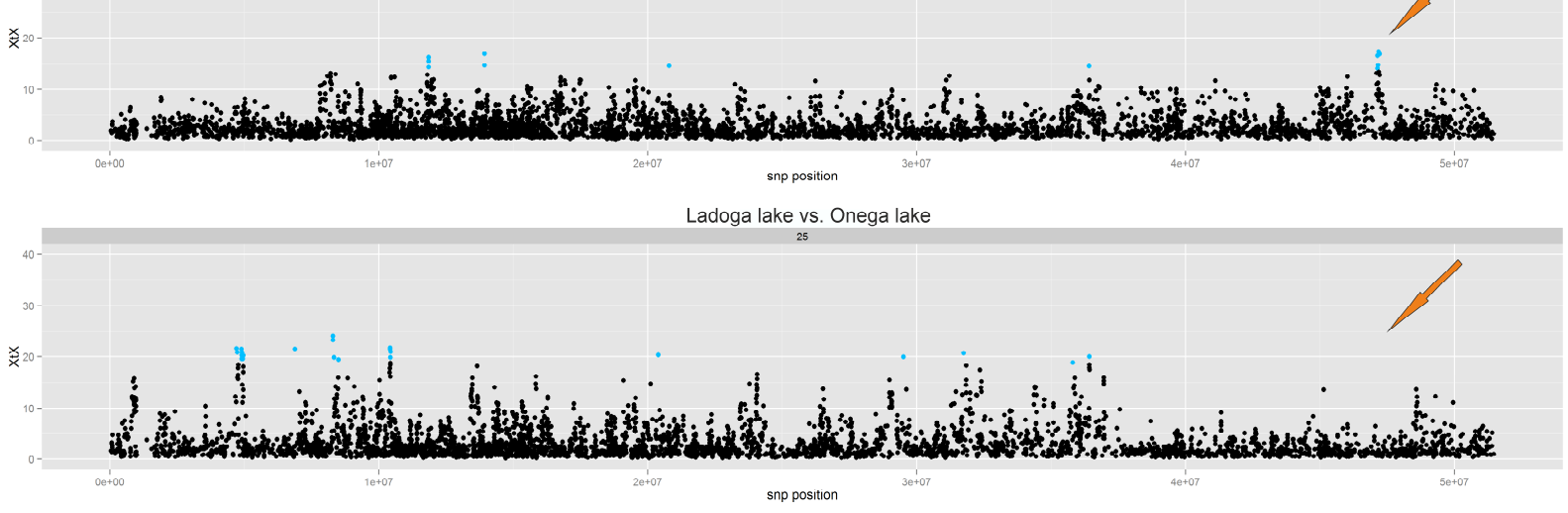

Figure 3. Levels of SNP differentiation (measured using the $X^{\mathrm{T}} X$ statistic, chromosome 25) between G. salaris susceptible (Barents \& White Seas) and resistant (lakes Onega and Ladoga) salmon stocks. Each dot represents one SNP, and outlier SNPs with elevated $\mathrm{X}^{\mathrm{T}} \mathrm{X}$ (above 99.5\% percentile) are marked with blue. Arrows indicate one candidate region associated with differences in parasite response, characterized by a high density of outlier SNPs in both "resistant vs susceptible" comparisons, but absent from the "resistant vs resistant" test. (Figure 3 is intended as a 2-column fitting image; colour) 


\section{Non-anadromous Ladoga lake}

1 Taipale 30

$2 \quad$ Hiitola

3 Sysky*

4 Uuksa

5 Tulema

6 Vidlitsa

\section{Non-anadromous Onega lake}

7 Shuya 31

8 Lizma 23

9 Kumsa

10 Pyalma*

11 Tuba

\section{Anadromous Barents Sea}

$\begin{array}{llc}12 & \text { Tenojoki_1 } & 32 \\ 13 & \text { Tenojoki_2 } & 13 \\ 14 & \text { Näätämo } & 24 \\ 15 & \text { Titovka } & 38 \\ 16 & \text { Z_Litsa } & 43 \\ 17 & \text { Ura } & 44 \\ 18 & \text { Tuloma* } & 40 \\ 19 & \text { Kola } & 40 \\ 20 & \text { Drozdovka } & 48 \\ 21 & \text { Yokanga } & 39\end{array}$

\section{Anadromous White Sea}

$\begin{array}{lll}22 & \text { Kachovka } & \\ 23 & \text { Ponoi } & \\ 24 & \text { P_Lebyazia* } & \\ 25 & \text { Danilovka } & \\ 26 & \text { Sneznitsa } & 25 \\ 27 & \text { Sosnovka } & 47 \\ 28 & \text { Babya } & 25 \\ 29 & \text { Lihodeevka } & 53 \\ 30 & \text { Pulonga } & 57 \\ 31 & \text { Ust_Pyalka } & 45 \\ 32 & \text { Strelna } & 64 \\ 33 & \text { Chavanga } & 42 \\ 34 & \text { Yapoma* } & 34 \\ 35 & \text { Indera } & 60 \\ 36 & \text { Varzuga } & 48 \\ 37 & \text { Olenitsa } & 46 \\ 38 & \text { Umba } & \text { Nilma } \\ 39 & \text { Pongoma* } & \text { Suma* } \\ 40 & \text { SD_Emtsa* } & 39 \\ 41 & \text { Megra } & 36 \\ 42 & & 36 \\ 43 & & \end{array}$

Table 1. Details of the studied Atlantic salmon populations: regional grouping, location, and 1261

$\begin{array}{ll}2000 & 60^{\circ} 37^{\prime} 26.4^{\prime}, \mathrm{N}, \quad 30^{\circ} 30^{\prime} 07.2^{\prime}, \mathrm{E} \\ 2006 & 61^{\circ} 11^{\prime} 56.5^{\prime}, \mathrm{N}, \quad 29^{\circ} 46^{\prime} 12.3^{\prime} \mathrm{E} \\ 1999 & 61^{\circ} 38^{\prime} 51.5^{\prime}, \mathrm{N}, \quad 31^{\circ} 16^{\prime} 18.3^{\prime}, \mathrm{E} \\ 2006 & 61^{\circ} 29^{\prime} 24.5^{\prime}, \mathrm{N}, \quad 31^{\circ} 35^{\prime} 54.0^{\prime} \mathrm{E} \\ 2006 & 61^{\circ} 21^{\prime} 25.0^{\prime}, \mathrm{N}, \quad 31^{\circ} 50^{\prime} 28.4^{\prime}, \mathrm{E} \\ 2006 & 61^{\circ} 10^{\prime} 32.7^{\prime}, \mathrm{N}, \quad 32^{\circ} 23^{\prime} 12.1^{\prime}, \mathrm{E}\end{array}$

1996

$61^{\circ} 52^{\prime} 00^{\prime \prime} \mathrm{N}, \quad 34^{\circ} 18^{\prime} 00^{\prime}$ ' $\mathrm{E}$

1996

$62^{\circ} 22^{\prime} 35.6^{\prime}, \mathrm{N}, \quad 34^{\circ} 30^{\prime} 18.9^{\prime}$ ' $\mathrm{E}$

2004

$62^{\circ} 54^{\prime} 31.4^{\prime}$ ' $\mathrm{N}, \quad 34^{\circ} 28^{\prime} 17.5^{\prime}$ ' $\mathrm{E}$

2001

$62^{\circ} 24^{\prime} 14.6^{\prime}, \mathrm{N}, \quad 35^{\circ} 52^{\prime} 24.2^{\prime \prime} \mathrm{E}$

2001

$62^{\circ} 15^{\prime} 00^{\prime}, \mathrm{N}, \quad 35^{\circ} 49^{\prime} 18.9^{\prime}$ ' $\mathrm{E}$

2001-2003

2001-2003

2006-2008

$69^{\circ} 54^{\prime} 59.5^{\prime}, \mathrm{N}, \quad 27^{\circ} 03^{\prime} 24.2^{\prime \prime} \mathrm{E}$ $69^{\circ} 25^{\prime} 55.0^{\prime}, \mathrm{N}, \quad 25^{\circ} 48^{\prime} 26.0^{\prime}$ ' $\mathrm{E}$ $69^{\circ} 42^{\prime} 27.9^{\prime}$ ' $\mathrm{N}, \quad 28^{\circ} 59^{\prime} 16.6^{\prime}$ ' E $69^{\circ} 28^{\prime} 48.6^{\prime}, \mathrm{N}, \quad 31^{\circ} 49^{\prime} 43.5^{\prime}, \mathrm{E}$ $69^{\circ} 24^{\prime} 30.3^{\prime \prime} \mathrm{N}, \quad 32^{\circ} 09^{\prime} 13.9 \mathrm{E}$ $69^{\circ} 17^{\prime} 29.7^{\prime \prime} \mathrm{N}, \quad 32^{\circ} 49^{\prime} 27.0^{\prime}$ ' E $68^{\circ} 40^{\prime} 12.7^{\prime}, \mathrm{N}, \quad 31^{\circ} 56^{\prime} 20.5^{\prime}$ ' $\mathrm{E}$ 68 49'00' $\mathrm{N}, \quad 33^{\circ} 05^{\prime}$ '00' ' $\mathrm{E}$ $68^{\circ} 17^{\prime} 29.1^{\prime \prime} \mathrm{N}, \quad 38^{\circ} 26^{\prime} 27.2^{\prime}$ ' $\mathrm{E}$ $67^{\circ} 59^{\prime} 54.4^{\prime}$ ' $\mathrm{N}, \quad 39^{\circ} 42^{\prime} 38.4^{\prime}$ ' E

2001

$67^{\circ} 26^{\prime} 30.9^{\prime \prime} \mathrm{N}, \quad 40^{\circ} 57^{\prime} 16.2^{\prime}{ }^{\prime} \mathrm{E}$ $67^{\circ} 07^{\prime} 27.6^{\prime \prime} \mathrm{N}, \quad 40^{\circ} 56^{\prime} 08.0^{\prime}$ ' $\mathrm{E}$

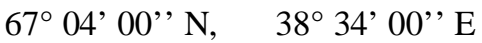
$66^{\circ} 44^{\prime} 25.0^{\prime \prime} \mathrm{N}, \quad 41^{\circ} 01^{\prime} 21.1^{\prime \prime} \mathrm{E}$ $66^{\circ} 34^{\prime} 47.6^{\prime}, \mathrm{N}, \quad 40^{\circ} 41^{\prime} 56.5^{\prime}$ ' $\mathrm{E}$ $66^{\circ} 30^{\prime} 33.2^{\prime}, \mathrm{N}, \quad 40^{\circ} 35^{\prime} 19.7^{\prime}$ ' $\mathrm{E}$ $66^{\circ} 23^{\prime} 16.0^{\prime}, \mathrm{N}, \quad 40^{\circ} 17$ ' 25.2' ' E $66^{\circ} 20^{\prime} 09.1$ ' $\mathrm{N}, \quad 40^{\circ} 10^{\prime} 46.5^{\prime}, \mathrm{E}$ $66^{\circ} 15^{\prime} 58.3^{\prime}, \mathrm{N}, \quad 39^{\circ} 58^{\prime} 18.4^{\prime}, \mathrm{E}$ 66 12' 00', $\mathrm{N}, \quad 39^{\circ} 30^{\prime} 00^{\prime}$ ' $\mathrm{E}$ 66 $66^{\circ}$ ' 33.4' $\mathrm{N}, \quad 38^{\circ} 38^{\prime} 22.6^{\prime \prime} \mathrm{E}$ 66 09' 00', $\mathrm{N}, \quad 37^{\circ} 46^{\prime} 00^{\prime}$ ' $\mathrm{E}$ $66^{\circ} 37^{\prime} 25.2^{\prime \prime} \mathrm{N}, \quad 36^{\circ} 12^{\prime} 10.0^{\prime \prime} \mathrm{E}$ $66^{\circ} 14^{\prime} 30.7^{\prime \prime} \mathrm{N}, \quad 37^{\circ} 08^{\prime} 43.2^{\prime}$ ' $\mathrm{E}$ 66 24' 00' $\mathrm{N}, \quad 36^{\circ} 37^{\prime} 00^{\prime}$ ' $\mathrm{E}$ $66^{\circ} 28^{\prime} 25.5^{\prime}, \mathrm{N}, \quad 35^{\circ} 20^{\prime} 11.1^{\prime}, \mathrm{E}$ 66 49' $06^{\circ}$ ' $\mathrm{N}, \quad 34^{\circ} 17^{\prime} 00^{\prime}$ ' E 66 30'04.3' ' $\mathrm{N}, \quad 33^{\circ} 08^{\circ}$ '04.3' ' $\mathrm{E}$ $65^{\circ} 17^{\prime} 00^{\prime}, \mathrm{N}, \quad 34^{\circ} 00^{\prime} 00^{\prime}$ ' $\mathrm{E}$ $64^{\circ} 16^{\prime} 58.9^{\prime}, \mathrm{N}, \quad 35^{\circ} 24^{\prime} 08.5^{\prime}$ ' $\mathrm{E}$ $63^{\circ} 30^{\prime} 36.9^{\prime}, \mathrm{N}, \quad 41^{\circ} 50^{\prime} 19.6^{\prime}$ ' $\mathrm{E}$ $66^{\circ} 09^{\prime} 24^{\prime}, \mathrm{N}, \quad 41^{\circ} 34^{\prime} 44.1^{\prime}, \mathrm{E}$ number of individuals pooled. Populations marked with asterisk $(*)$ have been studied previously in Zueva et al. 2014. 


\begin{tabular}{|c|c|c|c|c|}
\hline $\begin{array}{c}\text { Chromo- } \\
\text { some }\end{array}$ & Gene name & $\begin{array}{c}\text { Gene start, } \\
\text { bp }\end{array}$ & $\begin{array}{c}\text { Gene end, } \\
\text { bp }\end{array}$ & Gene product \\
\hline ssa01 & LOC106569418 & 142150894 & 142165267 & uncharacterized protein C18orf25-like \\
\hline ssa01 & LOC106608943 & 74119498 & 74124819 & chromobox protein homolog 7-like \\
\hline ssa01 & LOC106609330 & 74197728 & 74204071 & chondroadherin-like protein \\
\hline ssa01 & LOC106612532 & 93113743 & 93675639 & CUB and sushi domain-containing protein 1-like \\
\hline ssa03 & LOC106599503" & 19230012 & 19476371 & partitioning defective 3 homolog \\
\hline $\mathrm{ssa} 05$ & LOC106604946 & 40861196 & 40914104 & fibroblast growth factor receptor-like 1 \\
\hline $\mathrm{ssa} 05$ & LOC106605373 & 58379225 & 58400842 & $\mathrm{~N}$-acetylglucosamine-1-phosphodiester $\alpha$-N-acetylglucosaminidase (NAGPA)-like \\
\hline ssa06 & LOC106608134*" & 72162107 & 72202063 & serine/threonine-protein phosphatase $2 \mathrm{~A} 56 \mathrm{kDa}$ regulatory subunit $\gamma$ \\
\hline ssa07 & LOC106608623 & 13548236 & 13565188 & phospholipase A-2-activating protein-like \\
\hline ssa07 & LOC106608629 & 13151483 & 13287518 & serine/threonine-protein phosphatase $2 \mathrm{~B}$ catalytic subunit $\alpha$ isoform \\
\hline ssa10 & adgrl2 & 2603630 & 2817943 & adhesion $\mathrm{G}$ protein-coupled receptor L2 \\
\hline ssa10 & ddx11 & 86640661 & 86652856 & DEAD/H (Asp-Glu-Ala-Asp/His) box helicase 11 \\
\hline ssa10 & fkbp4 & 86653186 & 86669653 & FK506 binding protein $42 \mathrm{C} 59 \mathrm{kDa}$ \\
\hline ssa10 & hipk3 & 100391425 & 100436959 & homeodomain interacting protein kinase 3 \\
\hline ssa10 & LOC106560916 & 76184088 & 76220764 & sphingomyelin phosphodiesterase 3-like \\
\hline ssa10 & LOC106561152 & 83386500 & 83544652 & talin-2-like \\
\hline ssa10 & usb1 & 75766859 & 75773108 & U6 snRNA biogenesis 1 \\
\hline ssa11 & LOC106563271 & 66340506 & 66382645 & zinc finger protein 618-like \\
\hline ssa12 & LOC106566150 & 83440324 & 83569524 & kinesin heavy chain isoform $5 \mathrm{~A}$-like \\
\hline ssa12 & LOC106566244 & 90131368 & 90147215 & inositol-pentakisphosphate 2-kinase-like \\
\hline ssa13 & LOC106567000 & 32769414 & 32851876 & disco-interacting protein 2 homolog B-A \\
\hline ssa15 & LOC106571754* & 51217329 & 51409612 & utrophin-like \\
\hline ssa15 & stxbp5 & 52022403 & 52213226 & syntaxin binding protein 5 (tomosyn) \\
\hline ssa15 & tmem251 & 40830323 & 40857942 & transmembrane protein 251 \\
\hline ssa16 & bend7 & 23356567 & 23364386 & BEN domain containing 7 \\
\hline ssa16 & LOC106573414 & 23323009 & 23327401 & kelch repeat and BTB domain-containing protein 13-like \\
\hline ssa16 & LOC106573416" & 23343331 & 23354806 & selenide $2 \mathrm{C}$ water dikinase 1 -like \\
\hline ssa16 & LOC106573427 & 23563538 & 23623694 & $\mathrm{C} 2$ domain-containing protein 5 -like \\
\hline ssa16 & LOC106573506 & 27440279 & 27710925 & nuclear receptor ROR-alpha-like \\
\hline ssa16 & LOC106573509 & 22715465 & 23002856 & SH3 and multiple ankyrin repeat domains protein 3-like \\
\hline ssa16 & LOC106573702 & 32362952 & 33047110 & cadherin-13-like \\
\hline ssa17 & LOC106576270 & 44492421 & 44504981 & transcription factor Spi-C-like \\
\hline ssa18 & LOC106576912 & 12854410 & 12857878 & T-cell leukemia homeobox protein 1-like \\
\hline ssa20 & atp2a2 & 18887587 & 18934973 & ATPase $2 \mathrm{C} \mathrm{Ca++} \mathrm{transporting2C} \mathrm{cardiac} \mathrm{muscle} 2 \mathrm{C}$ slow twitch 2 \\
\hline ssa21 & baz $2 b$ & 14640471 & 14732354 & bromodomain adjacent to zinc finger domain $2 \mathrm{C} 2 \mathrm{~B}$ \\
\hline ssa21 & LOC106582019 & 24697123 & 24759127 & guanine nucleotide exchange factor DBS-like \\
\hline ssa22 & LOC106582736 & 9175335 & 9458601 & protein FAM19A2-like \\
\hline ssa22 & LOC106582832 & 12436441 & 12558962 & SLIT-ROBO Rho GTPase-activating protein 2-like \\
\hline ssa22 & pocla & 59808411 & 59890914 & POC1 centriolar protein A \\
\hline ssa24 & ndufaf2 & 7520982 & 7558381 & NADH dehydrogenase (ubiquinone) complex I2C assembly factor 2 \\
\hline ssa25 & LOC106586888 & 47217827 & 47228437 & interferon-induced GTP-binding protein Mx-like \\
\hline ssa25 & LOC106586889 & 47139132 & 47161992 & interferon-induced GTP-binding protein Mx-like \\
\hline
\end{tabular}


1263 Table 2. Candidate genes under positive selection based on overlap between the Bayenv2.0 1264 and BayeScan2.1 tests. Genes harboring SNPs that are among 50 the most differentiated 1265 SNPs are marked with (*) if they appear in Barents \& White Seas vs. Ladoga comparison, 1266 and with (") if they are in Barents \& White Seas vs. Onega comparison. Genes that harbor 1267 non-synonymous outlier SNPs are noted in bold. 